Article

\title{
Breaching Barriers: The Fight for Indigenous Participation in Water Governance
}

\author{
Ryan E. Emanuel ${ }^{1, *(1)}$ and David E. Wilkins ${ }^{2}$ \\ 1 Department of Forestry and Environmental Resources, North Carolina State University, Campus Box 8008, \\ Raleigh, NC 27695, USA \\ 2 Jepson School of Leadership Studies, University of Richmond, 410 Westhampton Way, \\ Richmond, VA 23173, USA; dwilkins@richmond.edu \\ * Correspondence: ryan_emanuel@ncsu.edu; Tel.: +1-919-513-2511
}

Received: 30 May 2020; Accepted: 22 July 2020; Published: 25 July 2020

\begin{abstract}
Indigenous peoples worldwide face barriers to participation in water governance, which includes planning and permitting of infrastructure that may affect water in their territories. In the United States, the extent to which Indigenous voices are heard-let alone incorporated into decision-making - depends heavily on whether or not Native nations are recognized by the federal government. In the southeastern United States, non-federally recognized Indigenous peoples continue to occupy their homelands along rivers, floodplains, and wetlands. These peoples, and the Tribal governments that represent them, rarely enter environmental decision-making spaces as sovereign nations and experts in their own right. Nevertheless, plans to construct the Atlantic Coast Pipeline prompted non-federally recognized Tribes to demand treatment as Tribal nations during permitting. Actions by the Tribes, which are recognized by the state of North Carolina, expose barriers to participation in environmental governance faced by Indigenous peoples throughout the United States, and particularly daunting challenges faced by state-recognized Tribes. After reviewing the legal and political landscapes that Native nations in the United States must navigate, we present a case study focused on Atlantic Coast Pipeline planning and permitting. We deliberately center Native voices and perspectives, often overlooked in non-Indigenous narratives, to emphasize Indigenous actions and illuminate participatory barriers. Although the Atlantic Coast Pipeline was cancelled in 2020, the case study reveals four enduring barriers to Tribal participation: adherence to minimum standards, power asymmetries, procedural narrowing, and "color-blind" planning. We conclude by highlighting opportunities for federal and state governments, developers, and Indigenous peoples to breach these barriers.
\end{abstract}

Keywords: tribal recognition; Indigenous rights; environmental justice; clean water act; wetlands; Lumbee; Haliwa-Saponi; Coharie; Meherrin; pipelines

\section{Introduction}

Water governance is a collection of systems and processes involved in decision-making about the use, conservation, and protection of water [1,2]. Discourse on transboundary water governance often evokes images of rivers or aquifers that cross international borders and prompts geopolitical discussions about hydropower, natural resources or trade [3-6]. Increasingly, however, these discussions also involve Indigenous peoples and whether or not they are entitled to a voice in decisions about waters-be they rivers, lakes, aquifers, or oceans-with which they have always had intimate connections [7-9]. The United Nations Declaration on the Rights of Indigenous Peoples (UNDRIP) [10] has heightened attention, globally, on Indigenous participation in water governance since its passage in 2007. In particular, UNDRIP affirms that Indigenous peoples have rights to maintain spiritual relationships with 
waters of their territories (Article 25) and to give free and informed consent prior to the development or exploitation of their water and other resources (Article 32). The ideals of UNDRIP notwithstanding, water governance systems of dominant societies worldwide are very rarely designed to accommodate Indigenous peoples or their values concerning water and water-related landscapes [1,7,11-16]. Notable exceptions include the longstanding treaty-based co-management of fisheries by Native Nations and the state of Washington in the United States (US) [17,18], and more recent efforts by Indigenous peoples in New Zealand and in the US state of California to recognize specific rivers as beings with legal rights [2,19-22]. Regardless of whether or not governance systems are designed to accommodate their values and voices, Indigenous peoples must frequently enter these arenas to defend their treaty rights, exercise their sovereignty, preserve their cultures, or protect their interests in other ways. To do so, they must often overcome barriers in governance, regardless of whether international borders are involved.

For Indigenous peoples, the cultural, historical, and spiritual significance of water often supersedes its value as an essential commodity. Significance may be assigned to water in general or to water-related places. For instance, the importance of water as a spiritual substance is articulated through Indigenous documents such as the Hopi Water Declaration, which eloquently affirms that "Water, the breath of all life, water the sustainer of all life, water the voice of our ancestors, water pristine and powerful" [23,24]. The cultural importance of water-related places also emanates from documents such as the Lumbee Tribe's ordinance to reclaim "Lumbee" as the ancestral name of the Lumber River in an act of "repatriating the tribe's cultural patrimony and primordial relationship with the river" [25].

Despite the importance of water to Indigenous peoples, and notwithstanding their pre-existing rights concerning water [10], substantial barriers exist to the meaningful participation of Indigenous peoples in all areas of environmental governance, including water governance. These barriers are especially high for non-federally recognized Tribes within the US, who often lack the standing and resources to participate meaningfully, if at all. In the US, non-federally recognized Tribes refer to Indigenous collectives whose inherent authority to self-govern is not acknowledged by the federal government. Some non-federally recognized Tribes hold recognition from state (i.e., sub-national) governments, and others lack recognition by any outside government whatsoever. Federal recognition (or lack thereof) is not an indicator of indigeneity or inherent sovereignty, rather, it is a legal and political status that determines whether the US is constitutionally bound to interact with the group as a sovereign nation [26-29].

The purpose of this article is to critically assess environmental governance challenges related to water that involve non-federally recognized Tribes in the US. In particular, we examine Tribes with state-level recognition (i.e., state-recognized) and the non-Indigenous actors with whom they share responsibility for environmental stewardship, especially corporations and regulatory agencies. We take a broad view of water governance, as have others working in this area [11,30,31], to include statutory responsibilities of non-Indigenous entities as well as cultural and moral accountabilities of Indigenous peoples towards the environment-especially to water-related landscapes that shape and define Indigenous territories and cultures.

We frame the challenges as transboundary because barriers faced by state-recognized Tribes often resemble obstacles to international transboundary water management, including misalignment of priorities and perspectives between governments working in different parts or at different scales of the same hydrologic system [8,32]. We focus primarily on North Carolina, which has the largest state-recognized Indigenous population in the US. The circumstances of Tribes in North Carolina are unique, but their challenges are in many ways similar to those faced by non-federally recognized Tribes elsewhere in the US.

Such a critical assessment is timely. Until recently, state-recognized Native nations in North Carolina have been relatively quiet on legal and policy issues related to environmental governance. Since 2014, however, efforts by outside parties to expand fossil fuel infrastructure into and through Tribal territories - with potential negative impacts for Indigenous peoples, their lands, and their waters-have spurred demands by state-recognized Tribal governments for treatment as sovereign 
Native nations during infrastructure planning and permitting. Some of these demands have come from the Nation to which both authors of this article belong: the Lumbee Tribe. Indigenous calls for participation, together with responses from regulators and developers, highlight barriers to entry into decision-making spaces that were not designed to accommodate Indigenous perspectives, especially perspectives of non-federally recognized Native peoples.

As Lumbee scholars, we have heard elders from our Tribe and from other non-federally recognized Tribes describe their situation as that of being "second class Indians" among US Tribal nations [33,34]. Elders who remember the Jim Crow era will sometimes add to the description, " ... and third class citizens." A similarly grim assessment could be made, regrettably, about the status of state-recognized Tribes in environmental governance. Many of the state-recognized Native communities mentioned in this article are actively seeking federal recognition, either through Congressional action or through the Bureau of Indian Affairs' administrative process. Both processes require years of preparation and waiting, substantial financial and intellectual resources, and-often-significant political capital. The stakes, however, are high. Federal recognition affords at least some ability for Tribes to protect the landscapes and waterways that have shaped and sustained their cultures and communities since time immemorial.

After reviewing major policy and structural challenges to participation in environmental decision-making by Tribes in the US, we present a case study from the southeastern state of North Carolina to illustrate how an accumulation of policies and actions by government and corporate actors excluded the Lumbee and neighboring Tribes from meaningful participation in the planning and permitting of a 1000-km shale gas pipeline, the Atlantic Coast Pipeline (ACP). The pipeline was proposed in 2014 and ultimately cancelled in 2020 following substantial delays, cost increases, and legal challenges. The ACP route traversed a swath of West Virginia, Virginia, and North Carolina that impacted approximately 30,000 Native residents (mostly Lumbee citizens) and multiple Tribal territories [35]. The pipeline had both immediate and long-term relevance to water. Construction would have affected more than 1500 water bodies (rivers, streams, swamps, and other wetlands) with open trenches, horizontal directional drilling, cofferdams, and a variety of other activities that temporarily or permanently impact water flow, water quality, flora, and fauna [36]. Developers expected to operate the ACP for several decades [37], a plan that would have had negatively impacted the region's greenhouse gas budget due to end-use emissions and methane leaks throughout the supply chain [38]. The ACP ran counter to recommendations from the global climate science community to transition rapidly away from shale gas and other fossil fuels to avoid the increasingly negative impacts of climate change on water supplies and freshwater ecosystems [39]. In Lumbee territory, some of these impacts include droughts, floods, and the potential degradation of culturally important wetlands and other environments [40]. Thus, the ACP had wide-ranging implications for Lumbee people and for the expansive network of wetlands, streams, and interstitial uplands that delineates their home territory and helps define collective Lumbee identity [41-43]. Although governance systems are nominally designed to protect the integrity of water and water-related places, the case study reveals difficulties faced by the Lumbee Tribe and other state-recognized Native nations expecting to participate in these systems.

We conclude by summarizing structural barriers to Indigenous participation in environmental governance. We place barriers into four general types: adherence to minimum standards, power asymmetries, procedural narrowing, and "color-blind" planning. We also highlight opportunities to breach these barriers and recommend actions for state and federal governments, corporations, and Indigenous peoples. Such actions could empower Native peoples to participate meaningfully-and collectively - in future decision-making processes, if not lead these processes outright.

\section{Borders and Barriers}

Indigenous territories can be delineated by rivers, watershed divides, coastlines, and other natural waters. Waterways may cross or form present-day geopolitical boundaries, or they may exist entirely 
within political borders. Indigenous territories, including waters within these territories, may or may not be recognized or respected by other governments. Thus, the rights of Native peoples to govern or exercise jurisdiction over their waters vary from community to community and nation to nation. For example, Tribal nations that are federally-recognized have had their rights to water recognized-if not always fully respected-since the landmark US Supreme Court decision, Winters v. United States [44], handed down in 1908. Winters held that when the federal government created Indian reservations, the lands and the peoples inhabiting those lands were implicitly entitled to allocations of water necessary to fulfill the purposes for which the reservation had been established. Although water was scarcely mentioned in most diplomatic accords between the Tribal nations and the US, Winters ruled that by creating reservations, the US implicitly established water rights to aid in the survival and development of Native nations [45].

Although federally recognized Tribal nations are subject to congressional plenary power, a problematic and damning doctrine that provides federal officials with virtually unlimited political power over Native nations, Tribes retained a bevy of inherent powers, including the right to administer environmental laws and ordinances within their own territories. State-recognized Tribes, on the other hand, enjoy far fewer governing powers and rarely control reservation lands $[28,46,47]$. To be clear, all Native nations face barriers to meaningful exercise of their rights. However, state-recognized Tribes face substantially more barriers stemming from their lack of authority to exercise certain rights.

Nominally, federal recognition provides Tribal nations with access to spaces where high-level decisions are made about the environment, including decisions about who has access to water and for what purposes. The Winters doctrine applies to federally recognized Native polities with reservations or other lands delineated with federal involvement—-be it via treaty, agreement, executive order, secretary of interior action, or judicial decree. The doctrine provides Tribal nations with critical access to spaces where decisions are made about water allocation. However, Winters is hardly the only mechanism by which Tribes participate in decision-making about water. For example, federally recognized Tribes have a comparable level of authority as states within their reservations to administer sections of the Clean Water Act, the 1972 federal law governing pollution discharge and impacts to wetlands and streams [48]. Other specific rights may be codified in treaties, negotiated through policy discussions, or determined in court proceedings.

On the other hand, state-recognized Tribal nations, including the Lumbee, have no guaranteed rights under Winters, other court rulings, or policies that apply to federally recognized Tribes. Instead, such Tribes rely on general policies that underpin US water governance. The most prominent of these are the doctrine of prior appropriation and the English common law of riparian water rights. The doctrine of prior appropriation prioritizes the allocations of earlier water consumers over later users, and rights to allocation can be lost if not fully used [49]. Prior appropriation governs the allocation of surface water throughout the western US. The riparian doctrine confers water use rights based on title to lands adjacent to streams. Prior use of water under the riparian doctrine does not create a vested right to perpetual use, and riparian owners do not lose rights by failing to use them [50]. Depending on where state-recognized Tribes are located, either or both of these policies may impact their water access rights. In general, state-recognized Tribes rely on US state governments to administer many water-related laws and policies, including, for example, sections of the Clean Water Act delegated to states for the regulation of pollutant discharges and other impacts to streams and wetlands.

For Native peoples, regardless of their present-day recognition status, various rights and challenges associated with environmental governance must be viewed through the lens of centuries of European and Euro-American colonization. In present-day North Carolina, for example, Native peoples have endured the negative impacts of colonization for more than 400 years. For most of that time, federal and state policies aimed to subjugate, eradicate, or assimilate Natives into the body politic. It was not until the self-determination era of the 1970s, exemplified by the passage of the Indian Self-Determination and Education Assistance Act of 1975, that Indigenous nations began to be allowed a measure of political, economic, and cultural autonomy [51]. Some Native nations in North Carolina and the 
broader region, including the federally recognized Eastern Band of Cherokee, have taken advantage of policy evolution to govern water and wetlands in their territories according to their own values and priorities [52,53]; however, even these communities still have to contend with barriers created by decades or centuries of policies and laws that evolved without their participation.

With the exception of the Eastern Band of Cherokee, Native nations presently residing in North Carolina have no recognized treaties with the US and cannot argue that they have guaranteed legal water rights under colonial law besides those afforded anyone under the riparian doctrine. Because these Tribes lack the benefits of federally sanctioned treaties and trust protections, they are largely excluded from any benefits of evolving policies toward federally recognized Tribal nations. Thus, state-recognized Native nations have had to battle on their own to breach administrative barriers set up without their involvement or consent.

Whether or not Indigenous peoples participate in discussions about policies, regulations, and permitting represents a different kind of boundary in environmental governance. Instead of a geopolitical border, this boundary grows from the accumulated actions and decisions of institutions. These actions and decisions often combine to de-emphasize or ignore altogether the perspectives, values, and experiences of Indigenous peoples. Globally, Indigenous peoples continue to face these types of boundaries in wide-ranging environmental decision-making activities that include forest management [54,55], climate change mitigation and adaptation [56,57], resource extraction [13,14], and infrastructure siting $[58,59]$. Whether through a single permitting action or centuries-long legal and political developments, we contend that the exclusion of Indigenous voices is a self-reinforcing process; exclusion today breeds exclusion tomorrow.

Exclusion from governance spaces has shackled the efforts of Native nations to manage many aspects of existence, including the often-sacred relationship between living beings and water. Thus, barriers raised through exclusion pose formidable challenges to Tribes, regardless of whether or not international borders are involved.

\section{Indigenous Peoples and US Water Governance}

Indigenous interests in water governance may extend beyond provisioning clean water and building resilience in the face of floods or droughts. Although these and other governance objectives are important, and although US Tribal nations participate in efforts toward these ends, Indigenous priorities may also include protecting water and water-related landscapes for diverse historical, cultural, and spiritual reasons (Section 3.1). In some cases, Native peoples do not have direct jurisdiction over these waters and must use other strategies, including government-to-government consultation, to ensure that their perspectives are fairly considered during decision-making (Section 3.2). State-recognized Tribes are not guaranteed consultation-flawed as the process may be-and face additional barriers to participation in decision-making and other aspects of governance (Section 3.3).

\subsection{Indigenous Perspectives on Water and Water Governance}

Throughout the US, Indigenous perspectives on water may lead to governance strategies that share objectives with federal and state water laws and policies, including a desire to provide ample, clean water for a variety of human and non-human uses [60,61]. However, Indigenous peoples may be motivated by other priorities, including deep, identity-defining connections to specific rivers, coastlines, wetlands, and other waters. These connections go beyond protecting water as a commodity or resource; they point to the maintenance of traditional life ways, languages, and cultural practices. Food ways, for example, are one easily recognizable mode of connection between water and Indigenous peoples. Salmon, shellfish, and wild rice are frequently cited examples of Native foodways that are sensitive to water quality and depend on specific aquatic habitats [62-64]. In present-day North Carolina, the Lumbee River and its adjacent wetlands have long supplied Native peoples with fish, game, medicinal plants, building materials, and other resources [42]. 
Other connections, including religious ceremonies and historical commemorations, are critically important, even if their links to water quality or other environmental factors are less apparent. For example, the Lumbee Tribe holds special reverence for its namesake river as the stronghold of 19th century Indigenous leader, Henry Berry Lowry. From 1865 until 1872, Lowry led a multi-racial band in a guerrilla war, first against the Confederate Home Guard and later against state and federal authorities $[42,43,65]$. The Lowry band leveraged knowledge of the river and tributary swamps to conduct raids and evade capture for years. Lowry disappeared in 1872 but remains an enduring symbol of leadership and resistance for Lumbee people and others, many of whom consider the river to be a de facto memorial to Lowry [43].

Some Native communities adapt existing regulatory frameworks to reflect their own values and standards for safeguarding water and water-related places. For example, the Swinomish Tribe of present-day Washington has expanded existing methods for assessing and rating wetlands by incorporating traditional ecological knowledge about culturally significant plants to protect tribally managed wetlands [66]. Native peoples elsewhere have adopted novel strategies to protect specific waterways. For example, the Yurok Tribe of present-day California has recently granted personhood status to the Klamath River, which gives the river certain rights as well as legal standing in Tribal courts [21]. This action codifies, at least in Tribal court proceedings, the unique relationship between Yurok people and the Klamath River, which is part of their ancestral and present-day territory. Moreover, it builds upon a slow but growing trend of Tribal governments (and other national governments around the world) that are extending legal rights to the natural world, including the Ponca Nation of Oklahoma and the Ho-Chunk of Wisconsin, who in 2017 and 2018, respectively, adopted ordinances providing legal rights to their lands [67]. The Lumbee Tribe's 2009 ordinance to reclaim the ancestral name of their river [25] was largely symbolic and has no regulatory significance, but the act nevertheless reflects the river's centrality to Lumbee identity. These examples further highlight that Indigenous perspectives may inform decisions about waters or water-related landscapes directly under Tribal jurisdiction (e.g., Swinomish [66]), or they may apply to waters not under Tribal control (e.g., Lumbee [25]).

Other modes of Indigenous water governance move beyond internal policies, ordinances and regulations to critique external processes that prioritize state and federal perspectives while de-emphasizing Indigenous views. For example, the Water Protector movement, which organized in response to the federal government's authorization of the Dakota Access Pipeline (DAPL) across unceded treaty territory of the Oceti Sakowin, advocated not only for clean water but also for the rights of Indigenous governments to participate meaningfully in permitting decisions that impact tribally significant waters [68]. In 2016, representatives from more than 300 Tribal nations gathered near the Standing Rock Sioux Tribe's reservation in North Dakota to support the Water Protector movement [69]. Such broad support suggests that Tribes are well aware of the important-yet asymmetric-nature of water governance across boundaries and jurisdictions, viz., [70]. Moreover, the Water Protector movement illustrates the holistic nature of water governance strategies for many Tribes; critiques of laws and policies that determine whose voices carry weight in shared decision-making are well within the scope of their concerns. Although specific goals of preventing water pollution and other environmental harms are embedded in their critiques, the Water Protector movement highlights broader issues associated with policies that have long restricted Indigenous peoples from meaningful participation in high-level decisions about water governance [58].

Water Protectors echo an ancient understanding by Indigenous peoples that water is not only an essential substance for all life but is also integral to culture and collective identity. This intimate relationship can motivate Indigenous peoples to protect water and water-related places as precious resources, identity markers, or both. In any case, Indigenous perspectives on water may be infused with values that differ, fundamentally, from the values underpinning non-Indigenous water governance, which centers on defining limits to the exploitation, degradation and pollution of water. These differences can lead to both opportunities and challenges for Tribes who seek to secure water access, preserve specific waterways, or protect other interests. 


\subsection{Indigenous Participation: Strategies and Barriers}

Some Tribes have access to treaties, laws, regulations, and even informal processes that may strengthen their inherent rights to manage water or water-related places. In the US, one prominent example is the treaty-affirmed right of Tribes in Washington to co-manage fisheries together with state government, although free exercise of this right came only after a years-long, Indigenous-led civil disobedience campaign and intervention by federal courts [17,18].

In other instances, Native peoples may depend on additional policy levers to amplify their voices in permitting decisions that have implications for culturally significant waterscapes, including policies that are not centered explicitly on water. For example, although the National Historic Preservation Act (NHPA) centers the built environment [71], it also aspires to protect cultural landscapes, including waters of special significance to Tribal nations [72]. In the context of the NHPA, federal guidelines define Tribal cultural landscapes as places, including seascapes and riverscapes, that are "imbued with special meaning to past and present (I)ndigenous communities" [73]. Thus, these kinds of sites may be eligible for a modicum of protection through the NHPA even if they are not protected by federal, state, or Tribal environmental regulations.

Section 106 of the NHPA instructs federal agencies to consult meaningfully with federally recognized Tribes whenever the federal government is involved in activities that may impact cultural landscapes. Moreover, a Clinton-era executive order extends the consultation responsibility to all federal agencies whenever polices or permitting actions have implications for federally recognized Tribes. Also, in 2010, the US became the last signatory to UNDRIP [10]. Although UNDRIP is not a legally binding treaty, it does reflect the continuing development of international legal and customary norms and affirms the commitment of most international states to provide greater recognition and support for Indigenous self-determination and cultural autonomy.

Tribes have also leveraged federal environmental justice policy to help ensure that their perspectives are included in decision-making. The policy, enacted through a 1994 executive order [74], charges federal agencies with identifying and addressing racial and other socioeconomic disparities in government activities, including the issuance of permits for polluting or hazardous infrastructure. Goals of the policy include recognizing and elevating the voices and perspectives of marginalized groups, including Tribes, in environmental decision-making [26,35,75,76]. For Indigenous peoples, regardless of their recognition status, environmental justice policy complements Tribal consultation by providing additional context to help decision-makers understand disparities that further exacerbate impacts to Tribes [35]. For example, in the case of DAPL, the Standing Rock Sioux Tribe and Cheyenne River Sioux Tribe successfully argued in court that federal regulators had not adequately considered environmental justice when issuing permits for the pipeline to cross the Missouri River [77]. In this instance, however, the ruling came long after the pipeline was completed, and Tribes are still waiting for pipeline operators to comply with a court-ordered shutdown.

Statutes, orders and international statements, while important, are imperfect. Environmental justice analyses are frequently criticized as performative "box-checking" exercises, and similar criticisms are levied against Tribal consultation [35,78-80]. Concerns about Tribal consultation embedded in the Water Protector movement and other Indigenous-led movements highlight the widespread nature of this issue throughout US Native communities and Tribal territories (i.e., Indian Country). Charges of inadequate or inauthentic consultation are especially common in policy actions and permitting related to fossil fuel development. For example, when the Federal Energy Regulatory Commission (FERC) solicited comments in 2018 on proposed changes to its natural gas pipeline permitting policies, Native nations and individual citizens responded by reiterating longstanding concerns about FERC's consultation practices or reminding FERC of its trust responsibilities. The United South and Eastern Tribes, which represent twenty-seven federally recognized Tribal Nations, typified the responses of Indigenous commenters in its assertion that " ... only Tribal Nations can provide an accurate and acceptable assessment of the potential impact of a proposed project on cultural properties of concern to them" [81]. 
Problems with consultation are not limited to FERC. In 2016, the United Nations' Special Rapporteur on the Rights of Indigenous Peoples toured Tribal nations in the US and documented the federal government's widespread non-compliance with the Free, Prior, and Informed Consent provisions of UNDRIP [80]. Other problems resonate from the legacy of historic actions implemented prior to the era of formal consultation policies. Many international treaties and other binding instruments were implemented before Tribal consultation was required or readily practiced, and therefore lack consideration of Tribal perspectives. The Columbia River Treaty between the US and Canada serves as a prominent example: Native nations impacted by major dams and other infrastructure facilitated by the treaty were not involved in discussions leading up to the 1961 accord [7]. They had to wait more than 50 years, until treaty renegotiation discussions, for an opportunity to weigh in as sovereign nations alongside the US and Canada.

Of course, since Native nations are not full partners with non-Indigenous polities on the international level, it is no surprise that Indigenous perspectives are only sometimes sought out and accorded a dose of respect. Despite these powerful substantive and systemic problems, some Native nations have had a measure of success navigating the prevailing policy and legal landscape in ways that incorporate Indigenous knowledge into water management and prioritize Indigenous values in decision-making about water. In general, they do this by leveraging expertise, funding, and networking to strengthen their position in relation to other policy actors [82].

\subsection{Precarious Position of State-Recognized Tribes}

State-recognized Tribes generally lack access to the panoply of legal, political, and policy tools available to their federally recognized kin [40,60]. Individual Tribal citizens can freely participate in decision-making about water in their territories through public comment processes or by petitioning elected officials, but these mechanisms for individual participation are not equivalent to recognizing Tribal nations as collective sovereigns. Occasionally, non-federally recognized Tribes are treated collectively as stakeholder groups in the decision-making process. For example, Native nations, acting as interest groups may be engaged alongside other interest groups such as concerned citizen organizations or chambers of commerce in outreach efforts by industries whose regulated activities impact water. However, as we discuss in the case study, stakeholder or interest group designation does not ensure that a Tribe's perspectives and concerns will be accurately documented or incorporated into decision-making during regulatory proceedings. Such designation also ignores the unique role of Indigenous peoples as traditional decision-makers and stewards of land and water in their territories [9] and can leave Native communities at a severe political, legal and economic, disadvantage.

There are two additional risks when state-recognized Tribes only have status as stakeholders in environmental decision-making processes. First, being comparably situated alongside non-Indigenous organizations devalues centuries or millennia of Indigenous knowledge that may be relevant to the decision at hand and may even enhance or contextualize other types of information [83]. Consider, for instance, that the longest hydrologic records collected by the federal government only extend back to the 1880s [84]. This period of record pales in comparison to Indigenous knowledge about water availability, flooding, and other hydroclimatic phenomena that may date back thousands of years [85]. Moreover, Indigenous peoples who maintain close relationships to their ancestral lands and waters are often the first, and potentially best-equipped, polities to observe and describe environmental degradation and change [86]. Thus, Indigenous knowledge and place-based relationships are qualitatively different than those of typical public stakeholders.

Second, relegation to stakeholder status also undermines efforts of state-recognized Native nations to be viewed as holding and exercising inherent sovereignty. Non-federally recognized Tribes are de facto sovereign entities, but the US government generally does not interact with these communities in a government-to-government fashion and rarely acknowledges their de facto or de jure sovereignty [29,46]. Thus, stakeholder status can be perceived as a tacit dismissal of sovereignty for state-recognized Tribes. More subtly, the designation can create the false impression that decision-makers engage non-federally 
recognized Native communities at a similar level to federally recognized Tribal peoples. The case study (Section 5) explains some of the harms associated with this thinking. First, however, we provide background on Native nations and water in North Carolina.

\section{Native Nations and Water in North Carolina}

In present-day North Carolina, as in other places around the world, discussions about water and Indigenous peoples are inextricably linked to the historical reality and theory of colonialism-an oppressive system that sought to exploit and supplant Indigenous societies with western institutions and structures. This massive exploitation describes a devastating story of federal political and economic domination of Native peoples, their lands, their resources, and their identities [16,51,58,87]. Across the US, legal and policy concepts linked to colonialism, including the ensuing dependency for most Native nations, controls who can access water in various places and times, and for what purposes. For example, federal laws and policies determine who is entitled to use water (e.g., Doctrine of Prior Appropriation, Reclamation Acts, Irrigation projects, etc.), who has permission to impact streams or wetlands (e.g., Sections 401 and 404 of the Clean Water Act), and who is authorized to discharge pollutants into waterways (e.g., National Pollutant Discharge Elimination System). Federal and state regulations define what constitutes a pollutant, which uses deserve entitlement, who has priority to consume water, and what incentives or punishments ensure compliance with the rules. Although these measures have done much to promote clean water and sustainable water use, they are framed around the commodification of water and do not capture the full complexity or holistic nature of Indigenous peoples' views on water. This is generally the case in North Carolina, where several state-recognized Tribes maintain connections to water in their traditional and present-day lands (Section 4.1) but have had little involvement in historical policies dealing with water (Section 4.2). These Tribes have also had limited involvement in present-day efforts to address impacts of climate change or industrialization on water in their territories (Section 4.3).

\subsection{Native Peoples in North Carolina}

Due in part to a history of colonization, which long pre-dates treaty-making between the US and Tribal nations, the southeastern US is home to a relatively large number of Native nations that are recognized by individual states but not by the federal government. Forty-two of the sixty-two state-recognized tribes in the US (68\%) are located in the present-day boundaries of six southeastern states (Virginia, North Carolina, South Carolina, Georgia, Alabama, and Louisiana). In North Carolina, seven of the eight Tribes recognized by the state do not have federal recognition: Coharie, Haliwa-Saponi, Meherrin, Occaneechi Band of Saponi, Sappony, Lumbee, and Waccamaw Siouan (Figure 1). North Carolina regulates state-level recognition using a statutory process that began in the 19th century and presently involves substantial oversight from already-recognized Tribes [46].

The Lumbee Tribe is the largest in North Carolina and one of the ten largest Native nations in the US with more than 60,000 enrolled citizens. The Lumbee, however, are uniquely situated and have partial federal recognition under P.L. 84-570-the so-called "Lumbee Act" of 1956-a federal law from the Termination Era that recognized the Lumbee people as Indigenous while simultaneously denying the Tribe and its members access to federal resources and benefits that other federally recognized Tribal nations received $[40,65]$. The prohibitive language of the Lumbee Act means that the Tribe is generally treated as state-recognized by non-Indigenous parties.

Of the eight Tribes recognized by North Carolina, only the Eastern Band of Cherokee Indians has full federal recognition as an American Indian Tribe. Citizens of the Eastern Band of Cherokee constitute approximately 10\% of North Carolina's Indigenous population, and their ancestral territory includes much of the southern Appalachian Mountain range and its foothills in present-day North Carolina and adjacent states. Regardless of their federal recognition status, all of the Tribes in present-day North Carolina are ancestrally connected to the Indigenous peoples who lived in various parts of the region and governed themselves prior to the founding of the United States. 


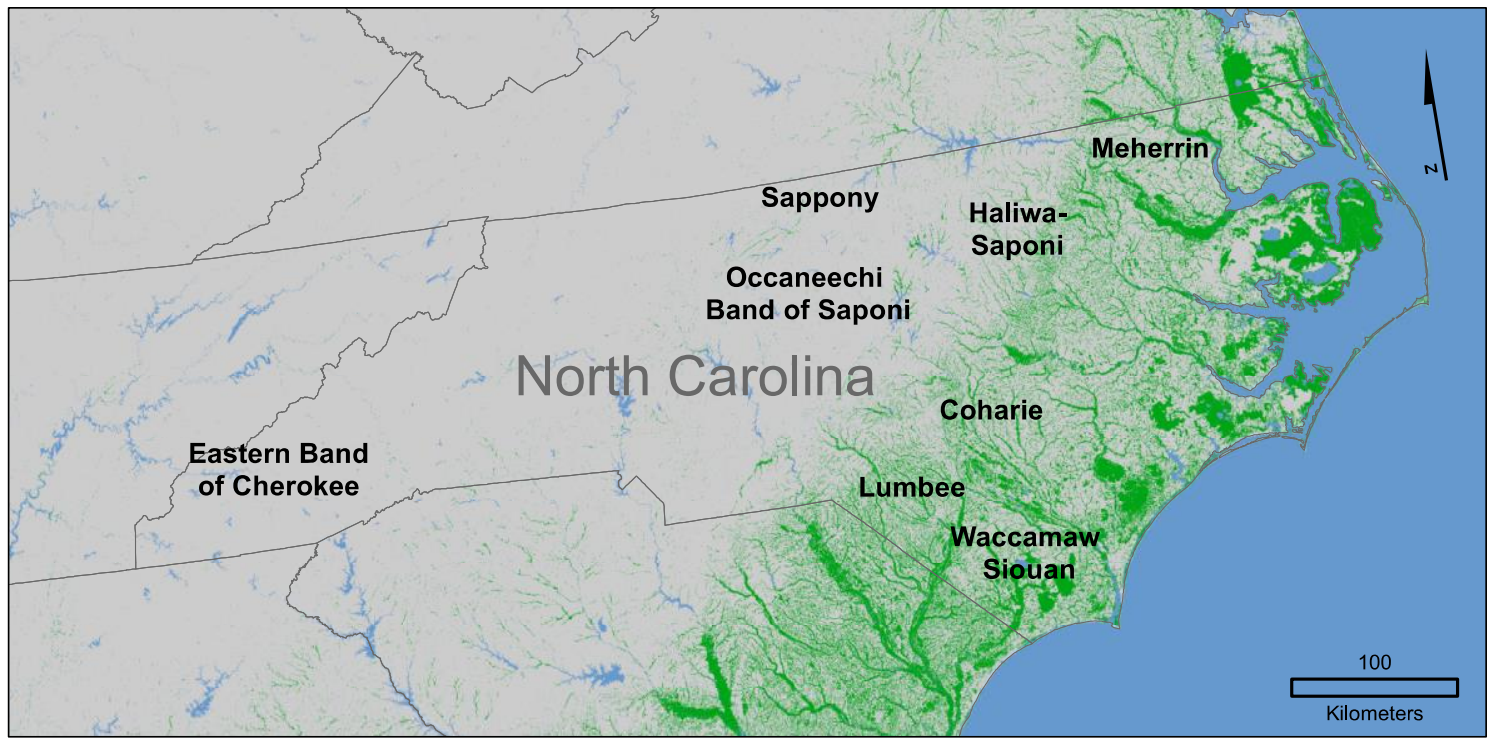

Figure 1. Tribal nations in present-day North Carolina. Names indicate approximate extent of present-day territories. Wetlands (green) and inland water bodies (blue) are adapted from the 2016 National Land Cover Dataset.

The state of North Carolina acknowledges an official service area for each state-recognized Tribe. State and Tribal governments mutually define a service area as a county or group of contiguous counties where the majority of Tribal citizens live, work and are eligible to receive housing and energy assistance or other services provided through Tribal programs. Because a majority of Tribal citizens reside in the service area, Tribes and non-Tribal entities consider service areas to be contemporary territories, and state government publications often represent them as such [88]. Conceptually, service areas are analogous to those delineated for federally recognized Tribes [89], except the Bureau of Indian Affairs does not define or operate in service areas of state-recognized Tribes within North Carolina.

In some cases, service areas overlap with traditional territories, but in other cases they do not. For example, prior to the early 18th century, traditional territories of Lumbee ancestors included areas from present-day North Carolina coast to the Piedmont of present-day North Carolina and Virginia [41]. However, the Tribe's service area today includes only Robeson and three adjacent counties. Decision-makers in North Carolina are not required to consult with state-recognized Tribes prior to policy or permitting actions that affect service areas. The state does not formally recognize traditional territories at all; Tribal communities (including elders, scholars, and other knowledge-keepers) are the primary authorities on these fluid and historically contingent geographies $[41,43]$.

In North Carolina and elsewhere, state-recognized Tribes have had to contend with legacies of exportation, betrayals, and racism that continue to inhibit their capacity to participate in environmental decision-making or wield inherent sovereignty in other ways. Tribes in neighboring Virginia, for example, including several that were non-federally recognized until 2018, were subjected to a "paper genocide" during the early 20th century that had been formulated and implemented by Walter Plecker, an avowed racist, who served at the state's registrar of the Bureau of Vital Statistics [90]. During this period, Virginia's vital records were revised to indicate that there were only two racial categories - "white" or "colored" - with Natives being categorized as either "mixed-blood negroes" or simply as "colored." In North Carolina, segregation limited education and career opportunities for Indigenous peoples throughout the state until the second half of the 20th century. Lumbee students, for example, while having the benefit of their own school after 1887, were not fully integrated in public schools until 1970 [43]. These practices, combined with a multi-generational absence of school curricula on contemporary Indigenous peoples in North Carolina and Virginia [91-93], reinforce the "US origin myth" [94] that Native peoples were either annihilated or removed from the region by the 19th 
century. Presently, neither state has a record of meaningful engagement with state-recognized Tribes on environmental issues, and Indigenous peoples are underrepresented in positions of environmental leadership (including corporate boards, legislative bodies, and regulatory agencies). The present situation is consistent with a legacy that involves the erasure of Indigenous identities and histories from the dominant culture.

\subsection{Physical and Political Geography of Water in North Carolina}

The southeastern US is often described as a water-rich region [95]. Hydrologically, this means that over the long-term, precipitation tends to exceed atmospheric demand for water, one characteristic of humid climates. Throughout the region, rivers and streams generally flow year-round, wetlands are regularly inundated or saturated, and aquifers are frequently replenished by infiltrating rainfall. The region receives relatively little snow, and rainfall varies from an average of less than $1200 \mathrm{~mm}$ per year in the Piedmont to more than $2000 \mathrm{~mm}$ per year in the southern Appalachian Mountains [96,97]. Headwater streams flow from the mountains and converge to form major rivers draining to the Atlantic Ocean (e.g., James River, Roanoke River, Pee Dee River, Catawba River) as well as tributaries to the Mississippi River (e.g., the Tennessee River and New River).

The hydrologic setting of North Carolina is fairly representative of the southeastern US as a whole. Water governance in the region has long reflected a desire to remove or re-route excess water from the landscape. Early colonial laws in North Carolina preserved the rights of individual property owners to drain excess water from their lands by digging ditches across neighboring properties [98]. From the colonial period through at least the mid-20th century, public policies in North Carolina and elsewhere in the Southeast incentivized the ditching and draining of wetlands [99]. Justifications for wetland drainage included increasing the amount of land available for crop cultivation, controlling water- and mosquito-borne illness, and facilitating the extraction of resources, including timber from forested wetlands and peat from drained landscapes [98,99]. As late as the 1970s, vast areas of wetland on North Carolina's Outer Coastal Plain were ditched and drained for large-scale row crop agriculture [100]. These priorities and challenges are significantly different from those that underpin water policy and law in the western US, where agricultural productivity and resource extraction are often limited by arid or semiarid conditions across most of that region.

During the 19th and 20th centuries, national policies also promoted the construction of dams and levees throughout the southeastern US [101]. The Tennessee Valley Authority oversaw the construction of approximately 30 dams for hydropower and navigation during the mid-20th century. As recently as the 1980s, the US Army Corps of Engineers completed a major flood control dam on North Carolina's Haw River to mitigate flooding in the city of Fayetteville, which is located on the Cape Fear River approximately $80 \mathrm{~km}$ downstream of the dam. Sections of rivers downstream of these dams can experience rapid and sometimes extreme fluctuations in flow, which often have negative ecological consequences for streams and their adjacent floodplains [102].

In the late 20th century, federal and state law-makers in the US changed course both on wetland drainage and on the regulation of flow on dammed rivers. As the benefits of wetlands for flood mitigation, pollutant and nutrient retention, and other environmental processes became clear, federal and state policies shifted from draining wetlands to preserving and restoring them. Other policies aimed to mitigate the further degradation and destruction of wetlands. In the 1970s and 1980s, a federal wetland policy of "no net loss" took shape [103]. This policy had major implications for the coastal plain of the southeastern US, which, despite centuries of drainage, still contains large areas of wetlands. In North Carolina, these wetlands include riverine swamps, floodplains, and other water-rich landscapes that still constitute large portions of territories for state-recognized Tribes in the coastal plain, namely the Lumbee, Coharie, Waccamaw Siouan, and Meherrin (Figure 1).

In the 1990s, parts of the southeastern US experienced intense droughts. They were not the first or most intense droughts in the historical record, but they occurred during a period of rapid population growth and urbanization. These events stressed water supplies throughout the region and launched 
legal standoffs between states over water rights. The most prominent dispute occurred between Alabama, Florida, and Georgia over access to water from the Apalachicola-Chattahoochee-Flint River Basin [104]. Model projections suggest that these types of droughts and water shortages will become more frequent in a warming world [95]. Thus, environmental regulators and other decision-makers have begun to re-think the concept of the southeastern US as a "water-rich" region.

\subsection{Native Nations and Water Governance in North Carolina}

Blackwater streams-so-named because of their dark-tinted waters from naturally high loads of dissolved organic matter [42] - flow throughout eastern North Carolina. These streams, which include the Lumbee, Great Coharie, and Meherrin Rivers, are definitive features of the territories of Native nations with whom they share names. The cultures and histories of these nations flow with these rivers and their adjacent wetlands [42]. Lumbee people often acknowledge the expansive swamps and black water streams as a source of protection from outsiders during the colonial and early US history [41-43]. Specific water bodies in the region feature prominently in oral traditions, including the Waccamaw Siouan Tribe's explanation of the origin of their namesake Lake Waccamaw [105], and the stories of Lumbee people whose ancestors migrated hundreds of kilometers to reach present-day Robeson County, North Carolina [41]. Other streams, such as the Great Coharie River, serve as present-day sources of recreation, sustenance, and cultural renewal through Native-led initiatives [106]. For these Tribes, environmental degradation or destruction could mean irrecoverable loss not only of socioeconomic resources but also of their identities as Indigenous peoples who belong in relationship with specific waters. Despite the high stakes, Indigenous peoples belonging to state-recognized Tribes are largely invisible in policies and decisions that affect the rivers, wetlands, and connected landscapes that make up their territories.

One of North Carolina's major environmental policies, Executive Order 80 [107], typifies the invisibility of Tribal Nations in this realm. Executive Order 80 is a state-wide policy intended to address climate change and facilitate a transition away from fossil fuels. It directs state agencies to assess the vulnerability of North Carolina communities to climate change, including a host of water-related issues. The executive order highlights roles for municipalities, colleges and universities, private businesses, and stakeholder groups in assessing and addressing climate change. Native nations, however, are not mentioned in the executive order or in follow-up documents related to sustainable energy and workforce development. Thus, North Carolina missed an early chance to include Tribes in its efforts to identify threats of climate change and to outline solutions that safeguard the unique relationships between Indigenous peoples and the waters they have stewarded since long before the establishment of North Carolina as a political state.

Waters and wetlands of cultural significance to the Lumbee and neighboring Tribes will likely be impacted by increasing hydrologic extremes from climate change [40]. The increasing frequency of both droughts and floods may alter hydrological and ecological processes of swamps and other wetlands that serve as community identity markers, provide traditional foods and medicines, and promote cultural preservation and renewal [40-42,108]. Recent examples of hydrologic extremes include devastating floods that followed Hurricanes Matthew (2016) and Florence (2018), both of which strained the capacities of local, state and Tribal governments to provide emergency services, disaster relief and long-term support to impacted communities. The floods caused several billion dollars of damage in the southeastern US and were major disruptors to life throughout the region, especially for Lumbee, Coharie and Waccamaw Siouan people, whose Tribal governments were already chronically under-resourced. The added burdens of disaster management, exacerbated by climate change, detract from resources that Tribes might otherwise direct toward initiatives such as housing or energy assistance, or toward efforts to manage and protect environmental resources in Tribal territories. Although Executive Order 80 was issued in late 2018, state officials have only recently (in 2020) initiated engagement efforts with Tribes in preparing for and adapting to climate change [109]. 
Tribal concerns remain absent from other areas of environmental governance in North Carolina. The proliferation of concentrated animal feeding operations and slaughterhouses during the last three decades has transformed rural landscapes and economies in the state and has major implications for water quality [42,110]. State laws and policies during the 1980s and 1990s encouraged the infrastructure build-out by providing tax breaks and exemptions from certain environmental rules for industrial livestock operations [111]. However, negative impacts on nearby waters and communities [110,112-114] led the state government to place a moratorium on new industrial swine facilities in $1997[115,116]$. Although the number of swine operations has not grown in the years since the moratorium, industrial poultry facilities have expanded largely unchecked due to similarly favorable policies. The combined footprint of industrial swine and poultry operations is greatest in eastern North Carolina, where North Carolina's Tribal populations are concentrated. Even so, Tribal governments were not involved in any of the major policy discussions to encourage or limit the growth of this industry.

State-recognized Tribal governments have also not been involved in policy decisions concerning fossil fuel pipelines and related infrastructure, despite threats to culturally important waterways, landscapes, and communities. Much of this infrastructure is concentrated in Lumbee Tribal territory. As the ensuing case study more fully describes, natural gas pipelines were first installed through Lumbee territory in the 1950s to provide gas service to eastern North Carolina. Since then, new transmission pipelines have been built or proposed, including the ACP. Most impacts of pipeline construction, including sediment pollution (a "serious but still underrated pollutant" [117]) and wetland degradation, are deemed minor and routine by regulators [118]. As a result, both state and federal governments typically use an expedited process to authorize pipeline impacts to streams and wetlands under Sections 401 and 404 of the federal Clean Water Act [118,119]. Critics of the federal expedited permit, Nationwide Permit 12, note that it limits opportunities for Tribal engagement in permitting, because it replaces a project-wide environmental review with individual-and expedited-reviews that focus only on water-body crossings [120,121].

Although federal regulators are required to consult with affected federally-recognized Native polities on Clean Water Act permits—even expedited permits—no such mandate exists for consultation with state-recognized Tribes [26,28]. North Carolina's counterpart to Nationwide Permit 12, General Certification 4133, also lacks this mandate [122]. The fact that state and federal regulators often use the same body of information to issue their separate authorizations (evidenced by a single, shared application for both authorizations [123]), creates an system in which state and federal decisions are not only mutually reinforcing but are also insulated against input from state-recognized Tribes due to lack of consultation requirements. The case study (Section 5) explores some of these entanglements further.

In North Carolina, state-recognized Tribes have experienced a small measure of success in their efforts to participate in environmental governance. For example, following Hurricane Matthew, the Federal Emergency Management Agency (FEMA) consulted with Lumbee Tribal government on a multi-million dollar buy-out program for properties in the Lumbee River floodplain. Although the properties were privately owned and buy-outs were negotiated with individual owners, the disposition of the properties involved a broader community discussion about flood mitigation and resilience. Given the cultural importance of the river and its natural floodplain, the Tribal government favored a plan that included green space and public access to the river [124]. Following discussions with Tribal and other governments, many of the properties were eventually transferred to the county government to be managed as green space $[125,126]$. Moreover, individual Tribal citizens can-and do-weigh in through advocacy, service in elected positions and other means, and state environmental officials hold seats on the Commission of Indian Affairs. However, North Carolina has no compulsory policy mechanisms for state-recognized Tribes to participate collectively, as governments, in environmental decision-making. Opportunities for meaningful engagement with these Tribes remain limited and sporadic. North Carolina, like many other states, has much room for improvement when it comes to incorporating Indigenous perspectives and knowledge systems into planning, permitting and other areas of water governance. 


\section{Case Study: The Atlantic Coast Pipeline and the Fight for Indigenous Participation in Water Governance}

A consortium of energy corporations announced the ACP on 2 September 2014 (Figure 2). The pipeline's two major proponents, Dominion Energy and Duke Energy, are publicly traded energy holding companies whose regulated utilities generate most of the electricity used in Virginia and North Carolina. The two companies hoped the $1000 \mathrm{~km}$ pipeline would make Appalachian shale gas more readily available to their affiliated utilities, which expect to replace coal with natural gas in the region's electricity mix. Initial estimates placed the cost of the ACP at between 4.5 and 5 billion USD, and predicted that it would begin delivering gas in late 2018 [127]. By the time it was cancelled in 2020, the cost had risen to 8 billion USD, making it the nation's most expensive gas pipeline [128]. Before announcing its cancellation, corporations had predicted that the ACP could be completed in 2022 [128], four years later than originally planned.

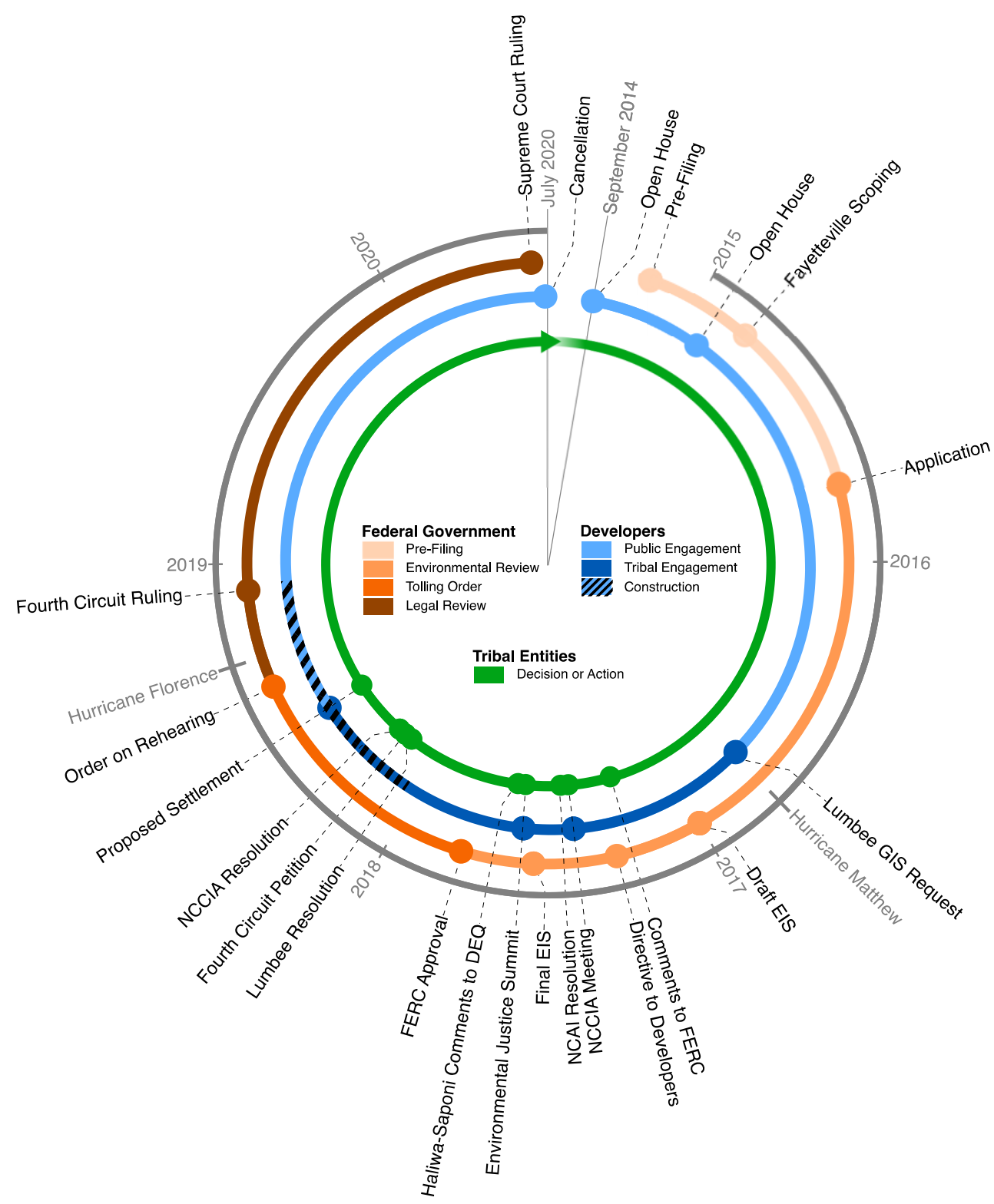

Figure 2. Timelines of activity by federal government, developers, and Tribal entities related to the Atlantic Coast Pipeline. Outer dial (gray) indicates year and timing of major hurricanes affecting Lumbee territory. Concentric rings show timing of key phases (colors) and specific events (black text). 
Energy companies developing the ACP (hereafter "pipeline developers" or "developers") required numerous state and federal authorizations. Applications for several authorizations triggered environmental reviews, including reviews of water-related impacts described in Section 1. Even though many of the impacts were expected to occur in service areas and traditional territories of state-recognized Tribal nations within North Carolina, these nations were not invited to participate in planning, permitting, or other decision-making surrounding the ACP (Section 5.1). Nevertheless, state-recognized Tribal governments insisted on a measure of participation as sovereign nations given the potential impacts on water and other aspects of their territories (Section 5.2). Despite the insistence of Tribes, developers and regulators generally avoided formal engagement with Tribes as sovereign nations, and in some cases pursued actions that further promoted the invisibility of Indigenous peoples in the regulatory process (Section 5.3).

\subsection{Planning and Permitting the Atlantic Coast Pipeline}

When the ACP was publicly announced in 2014, coal-fired power plants generated more than $40 \%$ of Duke Energy's electricity [129] and more than 25\% of electricity for Dominion Energy [130]. Earlier that year, a catastrophic spill of coal ash, a toxic by-product of coal-fired power plants, occurred at a Duke Energy facility adjacent to the Dan River, which supplies drinking water to cities and towns in North Carolina and Virginia. The spill contaminated approximately $100 \mathrm{~km}$ of the Dan River with selenium, arsenic, and other metals [131]. It brought new public scrutiny to a growing list of environmental and public health problems associated with coal-fired power [132]. The ACP was not proposed in direct response to the Dan River coal ash spill, but corporate executives have framed the pipeline as a necessary part of the transition away from coal and subsequent exposure to coal-related environmental and public health risks $[133,134]$.

The general route proposed for the ACP crossed streams and wetlands with cultural or other significance to several Native nations in present-day North Carolina, including the Meherrin, Haliwa-Saponi, Coharie, and Lumbee Tribes (Figure 3). The route also crossed tributaries of the Lumbee River, including swamps and streams in the heart of Lumbee territory, but it stopped short of crossing the main stem of the Lumbee River (Figure 3, Inset). The large number of swamps and other wetlands crossed by the proposed route was unsurprising given that wetlands make up approximately one quarter of the area of Robeson County, NC, where most Lumbee people live.

Lumbee leaders and leaders of other Tribes in present-day North Carolina were not involved in planning the general ACP route, and developers did not seek input or consent from the Tribe prior to routing the pipeline through Lumbee territory. The lead developer, Dominion Energy, planned the initial route during a one-week period in early 2014, reportedly without the aid of demographic or other socioeconomic data [135]. Absent data or expert knowledge about Indigenous peoples of the region, it is possible that route planners and other decision-makers were unaware of the large Indigenous populations and Tribal territories in areas targeted for the pipeline. Whether or not developers realized it, the route they chose through North Carolina traversed the traditional territories and contemporary service areas of at least three Tribes-Coharie, Haliwa-Saponi, and Lumbee-and the traditional territory of at least one additional tribe, the Meherrin (Figure 3).

Early on, ACP developers finalized the location of the pipeline's southern terminus [135]. Developers decided to locate the terminus in Prospect, a Lumbee farming community in Robeson County, North Carolina (Figure 3, Inset). Prospect lies near Pembroke, the political seat of the Lumbee Tribe and home of the University of North Carolina at Pembroke, an institution founded by Lumbee ancestors. Prospect is the oldest continuously inhabited Lumbee community and a center of Lumbee culture $[43,65,136]$. In 2010, the two US census tracts containing most of Prospect (Robeson County tracts $9604.01,9605.01)$ were among the most populous census tracts in the US for Indigenous peoples (more than 6000 and nearly 3000 American Indian residents, respectively). The approximate center of the community is Prospect United Methodist Church, one of the largest Christian congregations of Native people in the US [137]. Throughout its history, Prospect has been home to a host of Lumbee 
farmers, business leaders, scholars, and politicians. Signs along country roads leading into the community welcome travelers to "the cradle of Indian prosperity."

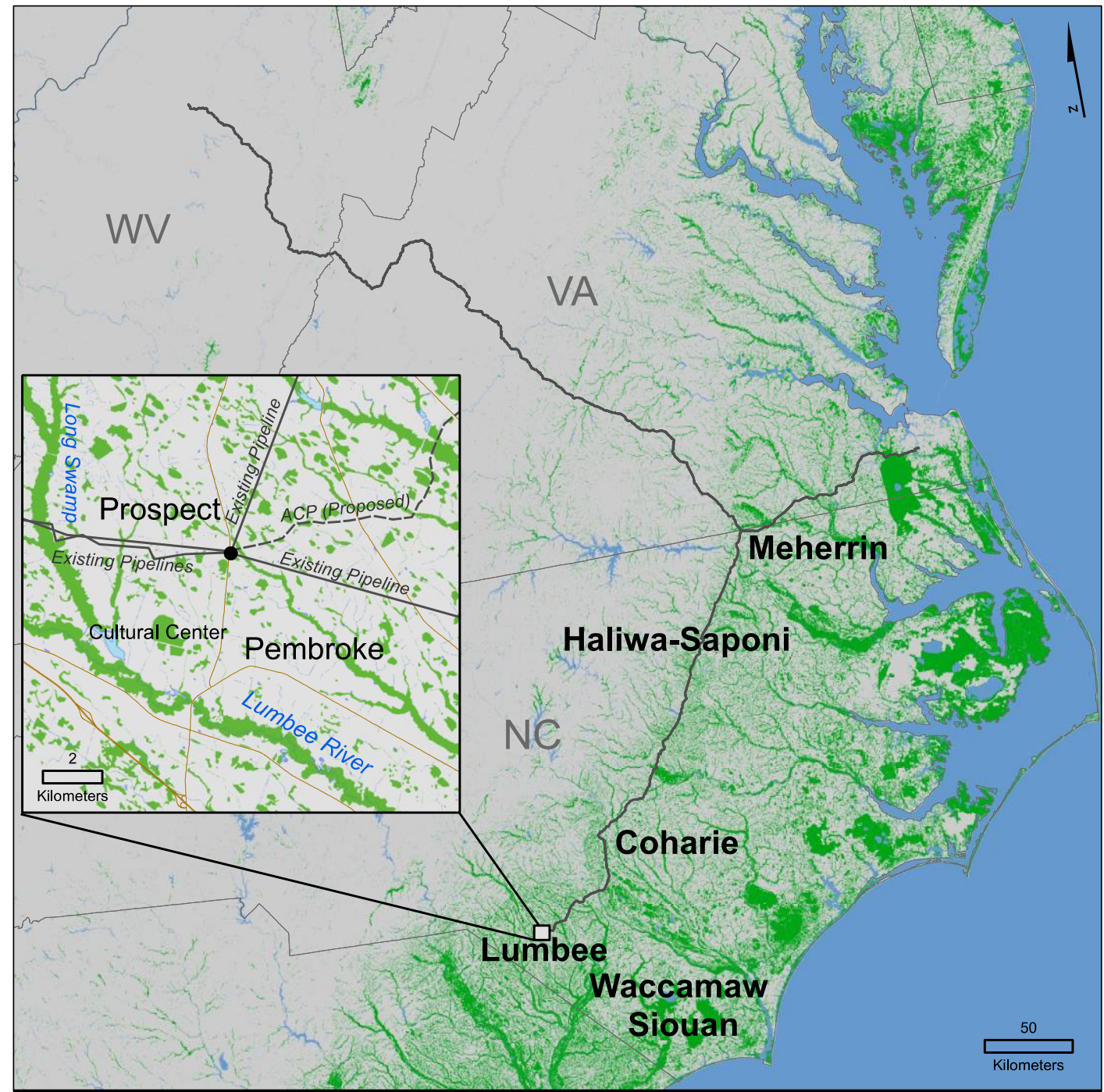

Figure 3. Proposed route of the Atlantic Coast Pipeline through West Virginia, Virginia, and North Carolina. Present-day territories of affected Tribal nations in eastern North Carolina are shown along with wetland land cover (green) and inland water bodies (blue) derived from the 2016 National Land Cover Dataset. Inset shows area surrounding Prospect, where developers proposed to build the Atlantic Coast Pipeline's terminal infrastructure (black circle). Highways and local roads (brown) are shown for additional geographic reference.

Long Swamp, a tributary of the Lumbee River, marks the western boundary of Prospect (Figure 3, Inset). Proximity to both Long Swamp and the Lumbee River gave the community a strategic role in the 19th century Lowry War, when densely-forested wetlands along both waterways served as hideouts and thoroughfares for Henry Berry Lowry and his band of guerrillas [42,43,65]. During the Great Depression, the federal government established a farming co-op, Red Banks Mutual Association, near the confluence of Long Swamp and the Lumbee River. The project was set up by the US Farm Securities Administration, and it was the only Depression-era farming co-op established exclusively for Native people [138]. In 1981, North Carolina's Governor and Commission of Indian Affairs (a state-wide intertribal advisory body) chose Red Banks as the site of a state-wide Native cultural center [139]. Currently, the Lumbee government manages the property as a cultural center for all Tribes in the state. 
The proposed pipeline terminus was less than $2 \mathrm{~km}$ from Prospect United Methodist Church, $4 \mathrm{~km}$ from Pembroke, and $5 \mathrm{~km}$ from the cultural center (Figure 3, Inset).

The terminus was sited near existing transmission pipelines and a compressor station in Prospect owned by Piedmont Natural Gas, a subsidiary of ACP developer, Duke Energy. The pipelines and compressor were originally constructed in 1959 as part of a 22 million USD project to provide natural gas to cities and towns of eastern North Carolina via a 1000-km network of new transmission pipelines [140]. The network originates in central North Carolina, where it taps into the Transco pipeline, a transmission line that runs between the Gulf coast and the northeastern US. The main trunk of the network runs east, through Prospect, where a major artery branches off to carry gas across northeastern North Carolina. The main trunk continues through Prospect, carrying gas into southeastern North Carolina. The compressor near this branching point has helped maintain gas flow through eastern North Carolina for more than half a century. Developers had hoped to supplement this flow with new gas supplies from Appalachian shale formations delivered via the ACP. As the rest of the ACP route took shape, the impacted area would eventually grow to encompass a population of more than 30,000 Indigenous people, almost entirely in North Carolina, with most living in the Lumbee Tribe's service area [35].

After identifying the general route of the ACP, developers began a newly instituted pre-filing process with FERC, the agency responsible for federal authorization of the project (Figure 2). During pre-filing, developers held open houses in cities along the pipeline route from late 2014 through early 2015. According to developers, the open houses were intended to convey information to the public about the project and to solicit input about "local needs and concerns" [141]. Informational literature and presentations by developers emphasized that the "best route" would depend on landowner input and the results of environmental, cultural, and historical assessments [142]. Around the same time, federal regulators held a series of public meetings to determine the scope of factors to be included in an environmental impact statement required by the National Environmental Policy Act. The closest scoping meeting to Lumbee territory was held in Fayetteville, NC, approximately $60 \mathrm{~km}$ away from Pembroke. No specific scoping activities were aimed at state-recognized Tribal communities.

During the scoping process, developers filed a series of reports intended to help inform FERC's environmental review. Some of these early reports list federally recognized Tribes contacted about the ACP during this time. A draft socioeconomic report from May 2015 is the first filing to specifically mention the Lumbee Tribe [143]. The 143-page document included a one-paragraph description of the Lumbee based on information retrieved from the Tribe's website in February 2015. The report did not mention Prospect or any specific Tribal territories that would be impacted by the project. The one-paragraph description of the Lumbee Tribe was omitted from final version of the socioeconomic report filed with FERC in September 2015, although the Tribe's website remained in the list of cited references [144].

The pre-filing and scoping periods culminated in the preparation of an Environmental Impact Statement (EIS) for the project. Pre-filing, scoping, and preparation of an EIS provide multiple junctures for federal regulators to engage meaningfully with Tribes during the environmental review process. However, there is no documentation that FERC interacted directly with Lumbee government officials during this time other than to circulate a Notice of Intent to prepare the EIS-a document distributed to more than 6000 parties. If the Lumbee Tribe had full federal recognition as opposed to partial recognition under P.L. 84-570, federal officials would have been required to initiate government-to-government consultation with Lumbee leaders during this period $[145,146]$. We acknowledge, however, that the consultation process itself is flawed and has been the subject of many calls for reform $[80,120,147,148]$.

Failure by FERC to engage with the Lumbee Tribe during critical early stages of the environmental review process, together with the failure of the developer's socioeconomic reports to identify the cultural significance to Lumbee people of the ACP's southern terminus were two key mis-steps that rendered Native people and their concerns largely invisible during important periods in planning and permitting. Of the two, FERC's omission was likely more serious, given the agency's responsibility to conduct a full review of project impacts, which include impacts to Tribes. The Coushatta Tribe 
of Louisiana summarized this point effectively in its response to FERC's 2018 call for comments on pipeline permitting policies: "Unless and until FERC meets directly (and not through the project sponsor) with affected tribes, it cannot know the project's true costs for that tribe" [149].

\subsection{Timeline of Actions Concerning North Carolina Tribes}

Although FERC did not engage in consultation or other direct interactions with the Lumbee or other state-recognized Tribes, pipeline developers sent form letters and materials to Tribes as part of their early public engagement efforts (Figure 2). Engagement materials [142,150] focused on recruiting support for the ACP among stakeholders. Some materials cited projections from an economic impact study that developers had commissioned for the pipeline [151]. These outreach efforts, however, were not designed to promote the involvement of Native governments in the federal environmental review. The first documented interaction between developers and the Lumbee government occurred in October 2016, approximately two-thirds of the way through the federal review process, and more than two years after the project was first announced publicly. In a letter to the Lumbee Tribal Chairman, Harvey Godwin, Jr. dated October 18, ACP developers asked if the Tribe had "comments or questions" about "potential impacts on archaeological sites, burials, and traditional cultural properties" prior to pipeline construction [152]. Records submitted to FERC show that Chairman Godwin and tribal administrator, Dr. Freda Porter, responded with a request for higher resolution GIS data of the route, and the developer sent a follow-up mailing in November 2016 [153].

The exchange between ACP developers and Lumbee officials did not involve requests for feedback on the overarching plan to build a pipeline at all or to locate its terminus in Prospect. In this respect, the exchange resembled outreach to individual landowners, which focused on the narrow question of identifying the "best route" [142] rather than soliciting input on the developers' broader plan. Strategic decisions about endpoints and whether to build a pipeline at all would likely have been finalized years beforehand, and certainly no later than late 2014, when ACP developers began the pre-filing process with FERC (Figure 2).

The brief exchange between Tribal officials and ACP developers in late $2016[152,153]$ was likely overshadowed by the Tribe's public service efforts in the wake of Hurricane Matthew. The hurricane, which struck the region in October 2016, caused unprecedented flooding throughout the Lumbee River basin [40]. In the months that followed, the Tribal government participated in-and sometimes led-emergency management and disaster recovery work, organized large volunteer efforts, and distributed food, clothing, cleaning supplies, and other aid to flood-ravaged communities, Native and non-Native, throughout the region [154]. The Lumbee government was stretched to the limit, and it had no dedicated staff to deal with environmental issues.

The nature and timing of communication between ACP developers and the Lumbee Tribe reveal potentially important information about the role of Indigenous knowledge—or lack thereof-in decision-making by pipeline developers. Specifically, the two-year delay between public announcement of the project and the late 2016 exchange with the Lumbee government suggests that Indigenous perspectives and expertise played no role in the developer's decision to route the ACP through Lumbee territory or to locate the terminus in Prospect. When developers finally corresponded with the Tribe $[152,153]$, their requests for input were limited to questions about the extent to which the ACP might damage or destroy Lumbee cultural resources, not about the general plan to build the pipeline in Lumbee territory. The broader plan was apparently not open to input from the Tribe. The situation thus resembled the misalignment of priorities sometimes encountered in transboundary water governance [8,32]. Moreover, the limited scope and late timing of developer interactions with the Lumbee Tribe echo tribal-corporate interactions related to DAPL and other fossil fuel projects throughout Indian Country [16]. That the communications occurred so soon after Hurricane Matthew was a combination of poor timing and bad luck.

In December 2016, following scoping and subsequent review, federal regulators released a draft EIS for the ACP [155]. The draft EIS did not mention Lumbee or other state-recognized Tribes. Moreover, 
the draft EIS concluded that minority communities would not be disproportionately impacted by the pipeline. That particular conclusion was based on a flawed environmental justice analysis that overlooked a disproportionately large Indigenous population in the area surrounding the pipeline route [35]. Here, disproportionality is defined from demographic data $[156,157]$ by comparing the fraction of Native individuals living in the study area to the fraction living in the surrounding reference area. Both areas, study and reference, were defined by FERC in the draft EIS, but in this case, errors in their study design led regulators to overlook the disproportionality [35].

According to demographic data included in an appendix to the draft EIS but not discussed in the document, Native peoples were more than ten times more likely to live in the North Carolina portion of the study area than in other parts of the state, and they were seven times more likely to live in the entire pipeline study area than in the three-state region as a whole. Overall, the ACP's study area contained one quarter of all Native peoples living in North Carolina. Approximately one-third to one-half of them were Lumbee citizens, based on census tract locations within the Lumbee Tribe's service area.

Officials from FERC not only failed to invite Lumbee and other state-recognized Tribes to weigh in as Native nations on the scope or details of the environmental review, but they also failed to acknowledge a serious racial disparity involving Native peoples. At least three Tribal governments-Lumbee, Coharie, and Haliwa-Saponi-and the North Carolina Commission of Indian Affairs (NCCIA) petitioned FERC to correct the oversight. In their comments to FERC, Tribal governments and NCCIA personnel highlighted issues of both unacknowledged racial disparities and lack of Tribal consultation. The Lumbee Tribe, in particular, criticized FERC and ACP developers for failing to interact with the Tribe "in a way that acknowledges its status as a tribal government" [158]. Comments from Lumbee leaders also noted that FERC mailings to inform the Tribe about the project had been addressed to a non-existent person within the Tribal government.

The National Congress of American Indians (NCAI), the largest and most influential Native interest group in the US, also weighed in. The group issued a resolution in June 2017 calling on state and federal officials to consult formally with impacted Tribes, particularly the Haliwa-Saponi Tribe, which proposed the resolution during a 2017 NCAI conference [159]. Notably, the NCAI resolution made no reference to recognition status when calling on ACP regulators to consult with Tribal governments, even though the NCAI comprised mainly federally recognized Tribes. The NCAI, NCCIA, and individual Tribes all argued that the environmental review required additional input and analysis to understand the unique ways in which the ACP might affect Native peoples and their territories.

Incorporating Tribal perspectives into federal decision-making is a key aim of Tribal consultation, but it is also a fundamental tenet of federal environmental justice policy. In the case of the ACP, federal regulators overlooked important details about federal policies on both environmental justice and Tribal consultation $[26,28,145]$. In addition to a demographic analysis that inappropriately masked the project's disparate impacts on the Lumbee and other Tribes [35], the scope of FERC's environmental review did not include unique risks to Native communities and their territories. Thus, it is no surprise that FERC listed as the project's main environmental justice concern, a "temporary increases in dust, noise, and traffic from project construction" [160]. Such a narrow view excluded a host of Tribal-specific concerns about impacts to culturally important landscapes and waterways, public health and community wellbeing, or property rights of Tribal citizens. These concerns were especially acute in Prospect, where developers planned to build—in addition to the pipeline itself-a metering and regulating facility and a 100-m tall telecommunications tower. The new infrastructure would add to the existing network of gas transmission pipelines and related facilities (Figure 3, Inset), all of which has been installed without the Tribe's input or consent. Unsurprisingly, Lumbee Tribal Chairman Harvey Godwin, Jr. described FERC's environmental justice conclusions as "unconvincing" in formal comments to FERC on the draft EIS [158].

FERC did not address critiques of the environmental justice analysis in its response to comments from Tribes and others. In response to requests for government-to-government Tribal consultation, FERC instead directed ACP developers to consult directly with Lumbee and other Tribes about the 
locations of specific sites and resources related to "traditional practices" [161]. However, FERC's directive was problematic for at least three reasons. First, the directive contradicted the agency's own policy against delegating tribal consultation to other parties [162]. Moreover, by focusing on two narrow topics, FERC limited the scope of wide-ranging concerns raised by Tribal governments and Indigenous organizations. Limiting the scope of Tribal engagement is not unique to the ACP, nor is it limited to FERC. A recent report from the US Government Accountability Office on Tribal consultation found that nearly half of the federally recognized Tribes surveyed (46 of 100) experienced some form of scope-limiting during consultations with federal agencies [148]. Finally, the directive came approximately three quarters of the way through FERC's formal review of the ACP (Figure 2), too late to incorporate Indigenous perspectives in any meaningful way.

FERC's directive to ACP developers raised an additional concern among Tribal leaders, because it lacked guidance about the protection of sensitive cultural information against potential misuse or abuse. These concerns were not wholly unfounded. FERC's directive came only a few months after culturally significant sites in North Dakota were reportedly destroyed by DAPL developers after the sites' locations had been shared by tribal historic preservation officers [16,163]. Native leaders and citizens in North Carolina were well aware of these and other issues surrounding DAPL. In 2016, the Lumbee Tribal Council passed a resolution supporting the Standing Rock Sioux Tribe and sent a delegation to North Dakota to support the Water Protector movement [164]. As a result of these concerns, some Tribes did not respond at all to outreach from ACP developers, and others responded by insisting on the federal government's involvement in such discussions.

In June 2017, soon after FERC's directive to communicate with Tribes, executives from the lead pipeline developer attended a quarterly meeting of the NCCIA. During the meeting, executives gave a presentation about the $\mathrm{ACP}$, describing job opportunities in the pipeline industry and the potential economic stimulus from the construction and operation of the infrastructure. Following the presentation, the Commission's environmental justice committee questioned ACP executives about FERC's implementation of federal policies concerning Tribal consultation and environmental justice, citing ongoing concerns with the draft EIS. Pipeline representatives deferred to federal regulators on both topics. For example, when questioned about the accuracy of FERC's environmental justice analysis, executives expressed confidence that FERC had followed EPA guidance. During the meeting, executives also acknowledged that their own outreach activities were not Tribal consultation as defined by federal policy or law $[145,146,162]$.

At the end of their quarterly meeting, commissioners voted to host a direct meeting between Tribal leaders and FERC to initiate consultation. However, FERC declined to send representatives to such a meeting, citing, among other factors, concerns over ex parte communications. As a quasi-judicial body, FERC is prohibited from engaging in such off-the-record communications while conducting environmental reviews and weighing decisions for pipeline projects. Tribes and advocacy groups have cited FERC's ex parte rules as a potential barrier to effective consultation $[165,166]$. In general, all parties note that ex parte rules do not apply during the pre-filing period, which further incentivizes early action by FERC to initiate consultation. FERC's April 2017 directive for the pipeline developer to consult with state-recognized Tribes-limited as it was-and the June 2017 counter-proposal by the NCCIA occurred long after the pre-filing period, which ended when ACP developers submitted their formal application to FERC in September 2015 (Figure 2).

After federal pipeline regulators declined to attend the NCCIA-sponsored consultation, the meeting — set for August 2017—was recast as North Carolina's first Tribal environmental justice summit. The summit was hosted by the Haliwa-Saponi Tribe at their headquarters in Hollister, NC, and it included representatives from all seven state-recognized Tribes in North Carolina as well as the Eastern Band of Cherokee, the lone federally recognized Tribe in the state. The US Environmental Protection Agency and the US Advisory Council on Historic Preservation sent specialists on environmental justice and Tribal consultation, and state environmental regulators attended as well. During the summit, Tribal leaders spoke unanimously about the failure of environmental permitting to acknowledge tribal 
concerns or engage meaningfully with Tribal governments. Tribal leaders specifically criticized FERC's refusal to consult with North Carolina Tribes during the environmental review for the ACP. By state law, the summit was open to the public because of its sponsorship by the NCCIA. Pipeline developers attended the meeting but were not on the speaking agenda.

Immediately after the summit, the Haliwa-Saponi Tribal government submitted detailed comments to the NC Department of Environmental Quality expressing concern about plans to approve the ACP [167]. The state agency had multiple roles in pipeline permitting, including authorizing impacts to streams and wetlands crossed by the pipeline in North Carolina. In their letter, the Haliwa-Saponi Tribe outlined concerns about the specific impacts of pipeline construction on water quality in streams within the Tribe's traditional territory. The letter also raised concerns about the high cost of the ACP and the plan for developers to recover capital costs from utility customers, noting that "... any possible rate increases caused by the ACP would be exceptionally difficult burden for our community to bear" [167]. Tribal officials also reminded state regulators that government-to-government consultation had yet to occur at either federal or state levels. The Haliwa-Saponi Tribe's letter is a salient reminder that Indigenous peoples can have complex, multi-faceted concerns about infrastructure such as the $\mathrm{ACP}$, including concerns about water, environmental justice and economics. To limit the scope of those concerns grossly oversimplifies the holistic view of land, water and community held by many Indigenous peoples.

\subsection{Indigenous Erasure}

In July 2017, FERC released the final EIS for the pipeline project [168]. The document re-articulated instructions for developers to meet with North Carolina Tribes, but it did not explain why FERC had contradicted its own policy on Tribal consultation. More than one year later, FERC would clarify that it had not, in fact, violated policy because the Lumbee and other state-recognized Tribes are not "Indian tribes" as defined by the regulations covering Tribal consultation [169]. Put otherwise, FERC held that best practices notwithstanding, the agency had no statutory requirement to consult with the Tribes. However, FERC had not yet publicly articulated that position when the final EIS was issued in July 2017.

The final EIS did not respond to criticisms raised by Tribal governments and others about racial disparities present in the pipeline study area. The uncorrected environmental justice analysis remained in the final version, and it continued to mask the project's out-sized impact on Native people as a whole. Without input from affected Tribes, regulators concluded that the environmental impacts of the project would be minimal, and FERC approved the ACP in October 2017 (Figure 2).

In its October 2017 approval, FERC cited the environmental review's lack of substantial environmental justice concerns. Immediately before FERC's decision was issued, pipeline developers submitted a report to regulators entitled, "Summary of Consultations with the Lumbee Indian Nation, Coharie Tribal Council, Haliwa-Saponi Tribe, and Meherrin Tribe" [170]. The report described the developer's visits to the Commission of Indian Affairs, attendance at the environmental justice summit, and various other activities. Several times, the report mentioned that Tribal governments were concerned about the "status of consultations." Although the developer's report did not elaborate on the phrase, "status of consultations" means that Tribal leaders were concerned that government-to-government consultations had still not taken place, yet FERC continued to move forward with authorizing the project [171]. The report also noted that Tribes did not disclose the locations of sacred sites or other sensitive information to developers. Despite the title of the report, these activities should not be conflated with government-to-government consultation cf. [147].

FERC's refusal to engage directly with state-recognized Tribes while simultaneously directing ACP developers to evaluate impacts to sacred sites or other cultural resources put Native peoples in a double bind. Accepting FERC's terms meant acknowledging the agency's denial of their sovereignty and relegation to a club-like status, comparable to a chamber of commerce, garden club or civic group. Refusing the terms meant being omitted from the environmental review and agency decision 
altogether. Either option would lead to the erasure of Lumbee and other state-recognized Tribes from the regulatory process. In the end, Tribes chose not to accept FERC's terms and insisted on treatment as sovereign Native nations. Despite the risk of having their voices excluded from the federal permitting process altogether, the prospect of continued treatment as "second class Indians" [33,34] was too much to bear. Thus, FERC's directive for developers to collect information from Tribal governments represents another type of entanglement, this one between developers and regulators, that effectively omitted Native peoples from the review process.

After federal authorization of the ACP, the North Carolina Department of Environmental Quality approved the pipeline's stream and wetland impacts by certifying the project under Section 401 of the Clean Water Act in January 2018. Notably, the Department of Environmental Quality adopted FERC's environmental justice analysis [35] instead of conducting an independent analysis. The state agency's reliance on a federal environmental justice analysis previously shown to mask disparate impacts on Native peoples is another example of the mutually reinforcing entanglements (Section 4.3) that can render Indigenous peoples invisible in water governance.

That same month, FERC allowed developers to begin logging and other so-called "pre-construction" activities along portions of the proposed route in advance of actual pipeline installation. In February 2018, each of the four US Army Corps of Engineers districts traversed by the ACP issued federal authorizations for water-related impacts using Nationwide Permit 12 [172]. The Corps did not consult with any state-recognized Tribes prior to authorizing more than 1500 water body crossings along the ACP route, including hundreds of crossings in North Carolina Tribal territories.

During this period, Indigenous peoples were again excluded from official narratives surrounding the project. A 2018 cultural resources report submitted to FERC by developers described eastern North Carolina as a land of "squatters, runaways, and outlaws" before the Tuscarora Nation was "driven out" in the 1700s [173]. In vivid terms, the narrative propagates the pervasive myth of colonialism: that settlers were pioneers who tamed empty lands [94]. Although Indigenous peoples are mentioned by name (Tuscarora), they are discussed only in the past tense and absent from the most recent 300 years of history. The report also omits the fact that one of the counties (Cumberland) lies within the Lumbee Tribe's present-day service area.

Ironically, the goal of the cultural resources report was to identify sites along the ACP route that may have been eligible for listing on the National Register of Historic Places. The register encourages listing of Tribal sites, including landscapes. According to the US National Park Service, which administers the Register, such sites are eligible for listing if they are important for maintaining "cultural identity" of a community or if they are associated with "traditional beliefs" of Native groups about origins, history, or the nature of the world [174]. The report, however, only reinforced the problematic idea that the only cultural or historic resources of concern to Indigenous peoples are those associated with pre-contact or early contact with settlers [175].

In February 2018, as tree-cutting began in earnest, the Lumbee Tribal Council passed a resolution [176] calling on state and federal regulators to suspend ACP permits issued without meaningful, government-to-government Tribal consultation and to deny future permits until consultation had taken place (Figure 2). The resolution noted that the ACP posed a "serious risk to the environmental and cultural resources of the of the Lumbee Tribe and its ability to provide a safe, livable homeland for its members and residents." The resolution highlighted the Tribe's reliance on waters along the proposed pipeline route for "sustenance," "medicines," and "general welfare" among other factors, and it cited the potential loss of hundreds of acres of "precious wetlands" to rights-of-way for the project. In the resolution, the Lumbee Tribal Council highlighted FERC's failure to consult with the tribe against the recommendations of the Advisory Council on Historic Preservation, the US EPA, and others.

Three weeks after the Lumbee Tribal Council's statement, the North Carolina Commission of Indian Affairs issued a similar resolution [177], calling for state and federal regulators to rescind permits that the Commission considered "incompliant with policy guidance from the United States Advisory 
Council on Historic Preservation and the United States Environmental Protection Agency, and directly opposed to Article 32 of the United Nations Declaration on the Rights of Indigenous Peoples." Both the Lumbee Tribe and the NCCIA argued for consultation from principled positions, just as the groups had argued to FERC during the federal environmental review. Although the groups' positions were consistent with federal guidance on Tribal consultation [28], the demands to rescind permits were not enforceable under political and legal norms codified in existing presidential executive orders or Section 106 of the NHPA. Similarly, their demands were consistent with Free, Prior, and Informed Consent language of UNDRIP [10], but that accord, as noted earlier, is not a binding international treaty and lacks enforceability under domestic or international law.

Nevertheless, copies of both resolutions were sent to state and federal agencies and to the governor of North Carolina. Neither resolution received an official response, and neither resulted in action to rescind permits or engage in consultation with the impacted Tribes. It is possible that the concerns of the two bodies could have been addressed at this point by suspending state and federal pipeline authorizations while regulators conducted consultations and prepared a supplemental EIS. Indeed, federal agencies may prepare a supplemental EIS whenever new environmental concerns are raised that were not evaluated in the original EIS [178]. However, there is no evidence that regulators seriously considered this remedy. A supplemental EIS may have been unappealing to developers as well, who were already behind schedule, having initially expected to gain FERC approval in mid-2016 and to begin transporting gas in 2018 [127].

In February 2018, on the heels of the Lumbee Tribal Council resolution, the Lumbee Tribe and Haliwa Saponi Tribe joined a petition to the US Fourth Circuit Court of Appeals [179]. The petition, led by environmental and other public interest groups, sought formal review of FERC's 2017 authorization of the ACP. Notably, one argument in the petition was that FERC's authorization came without formal consultation with the Lumbee and Haliwa-Saponi Tribes. However, the court did not have an opportunity to weigh this argument, because FERC had issued a tolling order on its ACP decision in late 2017. Tolling orders extend the statutory 30-day window for regulators to respond to challenges to agency decisions [180]. The orders are controversial because they prevent judicial review of FERC decisions while allowing certain construction activities to proceed [181]. The tolling order forced the court to dismiss the petition without review, deferring to FERC on the decision of whether or not to re-open the case for further investigation and input, including perspectives gained through consultation with Native governments.

In April 2018, environmental justice advocacy groups in North Carolina filed a civil rights complaint with EPA over DEQ's adoption in state-level permitting of FERC's environmental justice analysis [182]. Although Tribal governments were not directly involved in this action, the complaint cited relevant racial disparities overlooked in FERC's analysis. Specifically, the complaint alleged that DEQ violated Title VI of the 1964 Civil Rights Act by failing to acknowledge the disproportionately large Indigenous population affected by the ACP. However, by the time EPA completed its preliminary review of the case in August 2018, pipeline construction had been temporarily suspended due to loss of federal permits in court. In these cases, judges ruled that aspects of permitting decisions had been arbitrary and capricious including, for example, unenforceable guidelines about compliance with the federal Endangered Species Act [183]. EPA investigators determined that they could not rule on civil rights violations for a suspended project, and they dismissed the case without prejudice. Because both the court petition and the civil rights complaint were dismissed on procedural grounds, neither reviewed the merits of concerns related to Tribes.

In June 2018, soon after these legal and administrative actions, the Lumbee and Haliwa-Saponi Tribes were reportedly offered a financial settlement by the lead ACP developer if they agreed to cease opposition as Tribal nations to existing pipeline permits (Figure 2). A draft of the settlement agreement, which was shared with news media [184], suggests that the deal could have limited Tribes' ability to exercise their already-constrained sovereignty. Specifically, by ending calls for government-to-government consultation before FERC had decided whether or not to re-hear the case 
with additional input and perspective, the deal would have signaled that Native governments no longer sought a seat at the decision-making table through formal consultation or by any other means. Neither Tribe accepted the settlement. The Haliwa-Saponi Tribal Council voted against it. By contrast, the Lumbee Tribal Council passed a resolution supporting the settlement. Tribal Chairman, Harvey Godwin, however, refused to sign the agreement, citing his constitutional authority to execute contracts on behalf of the Tribe. Godwin vehemently opposed the settlement, referring to the offer as "hush money" during a speech at the 2018 North Carolina Indian Unity Conference, a statewide gathering of Native leaders, elders, and professionals. In a public statement, Godwin emphasized his responsibility to "uphold the Lumbee way of life and that includes protecting our voice" [185].

In August 2018, FERC ended the tolling order on its ACP decision by issuing an Order on Rehearing (Figure 2). In it, FERC summarily dismissed wide-ranging complaints about the ACP permitting process, including complaints related to Tribal consultation and environmental justice [169]. Here, the agency first revealed its opinion that it had no statutory requirement to engage in consultation with Lumbee and other North Carolina Native peoples because of their non-federal status (or because of the Lumbee Tribe's status under the 1956 Lumbee Act). For the first time, Tribes heard directly from FERC on why the agency had ignored consultation requests for nearly eighteen months. FERC argued that its actions were lawful because it applied the minimum legal standard of limiting consultation to the federal government's published list of recognized Native political entities. The argument may have been lawful, but it most certainly was not just; the agency's decision excluded Tribal governments representing virtually all of the 30,000 Natives living within the agency-defined study area for the ACP. FERC's August 2018 Order contains the first known application of the 1956 Lumbee Act to a request for Tribal consultation on an environmental review. It is a grim precedent.

The Order or Rehearing acknowledged that FERC considered state-recognized Tribes not as sovereign nations but "as members of the public with the same rights to comment and participate" [169]. This statement, together with FERC's late-breaking directive to developers to demonstrate communication with Tribes-issued near the end of the entire environmental review process (Figure 2)—suggests that the agency may have considered Tribal engagement a pro forma activity rather than an opportunity for Tribes to help shape the scope and details of the regulatory process. Moreover, FERC's decision to relegate Tribes to status of "members of the public" meant that Tribes did not receive the attention owed to sovereign nations whose territories were impacted by agency actions.

By 2018, state and federal legislators had also begun to weigh in on both sides of a growing political debate around the ACP. Lumbee Tribal leaders were especially sensitive to increasing politicization of the project, given the Tribe's active bid for full federal recognition in US Congress. Although Lumbee Tribal Chairman Godwin criticized pipeline permitting and vehemently opposed the attempted settlement with ACP developers [185], he was unwilling to potentially jeopardize the Tribe's recognition efforts through legal opposition to a pipeline that had powerful political entanglements [186]. Throughout this period, the Lumbee Tribal Council's 2018 resolution opposing ACP permitting remained in effect, but neither the Lumbee Tribe nor any other state-recognized Tribe pursued legal action on their own or joined a growing number of federal lawsuits against pipeline authorizations by non-Indigenous organizations. In late 2018, the Fourth Circuit Court of Appeals revoked three more of the pipeline's federal permits in response to some of these lawsuits. Pipeline developers had barely resumed construction following the previous permit-related suspension [183] before announcing in December 2018 that they would suspend all remaining work on the ACP while permitting issues were addressed in the courts (Figure 2).

On 5 July 2020, developers suddenly announced cancellation of the ACP (Figure 2). Despite a favorable ruling weeks before, in which the US Supreme Court reinstated a voided permit, developers announced that the project had become too risky due to delays, rising costs, and legal uncertainties [187]. Although North Carolina Tribes did not participate directly in any of the major legal challenges faced by the ACP, their absence from the courtroom did not mean Tribal governments were unconcerned. 
Instead, lack of legal involvement by Tribal governments may reflect-among other factors-the fact that state-recognized Tribes possessed limited resources to pursue court challenges, foresaw few paths to legal victory because of their recognition status, and understood the political implications of opposing powerful corporate actors.

\section{Breaching Barriers: Lessons from the ACP and Opportunities for the Future}

At the time of its cancellation, the ACP was estimated to be only six percent complete [188], meaning that many of the impacts and other concerns will never materialize. Nevertheless, the ACP offers important lessons about Indigenous participation in environmental governance. In particular, the case study reveals complexities of environmental planning and permitting from the distinct viewpoint of state-recognized Tribes. The process is complicated and multi-faceted, but it offers many entry points for Tribes to participate as sovereign national bodies in water governance. Specifically, the ACP's planning and permitting process offered several opportunities for decision-makers to acknowledge Indigenous peoples and to engage meaningfully with Tribal nations while planning the route and identifying its environmental and societal costs, including the impacts to the streams, wetlands, communities, and broader landscapes that make up Tribal territories. However, the case study also illustrates how easily decision-makers can raise barriers or otherwise deny state-recognized Tribes access to formal participation in permitting and other forms of governance. In this final section, we summarize barriers from the ACP case study (Section 6.1) and outline opportunities for the future (Section 6.2).

\subsection{Lessons from the ACP}

Federal regulators denied Tribes participation by citing the minimum legal standard for consultation rather than following the recommendations of federal advisory bodies, which emphasize that consultation with non-federally recognized Tribes "can enhance agencies' decision-making processes" [28]. Regulators also ignored relevant tenets of the UNDRIP, which affirm that "Indigenous peoples have the right to participate in decision-making in matters which would affect their rights, through representatives chosen by themselves in accordance with their own procedures" [10]. The declaration continues, "States shall consult and cooperate in good faith with the (I)ndigenous peoples ... in order to obtain their free and informed consent prior to the approval of any project affecting their lands or territories" [10]. By adhering to the legal minimum instead of following the recommendations of UNDRIP and other guiding documents, ACP regulators overlooked the ethical aspects of these recommendations, including the principles of Free, Prior, and Informed Consent. In doing so, they erected a major procedural barrier to participation in pipeline permitting by Tribes who had much at stake.

The case study also highlights how a second type of barrier to Tribal participation in environmental decision-making can be erected through power asymmetries between Tribes and other entities, a recurring theme in water governance across boundaries and borders [70,189]. Some asymmetries are easily recognizable. The ACP, which had a final estimated cost of 8 billion USD, was backed by multi-billion-dollar energy holding companies and supported by politicians, industry groups, and other powerful interests. The project and its backers wield far more societal and political influence than state-recognized Tribes, who lack even limited sovereign powers affirmed by federal recognition. For the Lumbee Tribe, however, it was not only the outwardly visible power imbalance that dissuaded leaders from opposing ACP authorization in court. Concerns about negatively affecting the Tribe's federal recognition bid weighed into Tribal leaders' decision to stay out of the courtroom. The case study shows that power asymmetries, whether outwardly visible or not, can have a chilling effect on Tribes and may pose formidable barriers.

A third type of barrier involves narrowing participation in ways that do not exclude state-recognized Tribes outright; rather, they shift or compress the scope and timing of engagement so that Indigenous perspectives cannot be incorporated adequately into decision-making. For the ACP, this 
involved both poorly timed engagement and scope-limiting by developers and regulators. By delaying Tribal engagement-indirect as it was_-until the federal review was nearing completion (Figure 2), regulators drastically curtailed the ability of Native nations to provide meaningful input into the decision-making process. By reframing consultation as a limited request for Tribes to disclose culturally sensitive information to pipeline developers prior to inevitable construction, regulators further limited Tribal contributions by narrowing the scope of input in ways that do not reflect Indigenous thinking about land, water, or communities. Delayed engagement and scope-limiting are not unique to the ACP, nor are they unique challenges experienced by non-federal Tribes [13,16,190-192]. Still, these forms of procedural narrowing add to the growing list of barriers faced by state-recognized Tribes.

One final type of barrier is erected through the omission of information, especially demographic data, from planning. For example, the case study highlights risks to environmental justice and Indigenous rights when pipeline planning lacks adequate demographic data or expert knowledge. This is especially true in parts of the southeastern US, where minority and low-income populations are often clustered in rural areas [193], which are often preferred by pipeline developers. For example, if Robeson County, NC were a separate state, its Indigenous population would rank thirteenth largest in the US. Even a cursory inspection of demographic data at the outset would have revealed to route planners that their initial selection for the southern terminus of the ACP was a major Indigenous population center, and inspections elsewhere along the route would have revealed that two of the pipeline's three compressor stations were sited in African American communities [194-196]. As early as 2014, developers could have re-routed the pipeline to avoid these areas, or they could have engaged in early conversations with Tribal nations and others to seek consent. Instead, developers committed to a general plan without seeking input or consent from Tribes. However, by the time developers approached Tribal governments, key decisions about the pipeline route and terminus had already been made.

We cannot say whether demographic data or expert knowledge would have caused route planners or corporate decision-makers to act differently at the outset. There is no evidence that eventual access to demographic data led decision-makers to acknowledge racial disparities and associated environmental justice implications. Nevertheless, deliberately excluding such information from the early planning process served no beneficial purpose and only exacerbated other issues. The practice resembles a so-called "color-blind" ideology that does not acknowledge, and therefore cannot address, structural racism [197]. For the ACP, such "color-blind" planning acted as a barrier to pre-emptive avoidance of negative impacts to Native communities and other marginalized peoples (e.g., [195]), who already bear an oversized share of environmental burdens in the region.

\subsection{Opportunities for the Future}

The ACP case study not only reveals barriers to participation by Tribes in environmental governance related to pipeline permitting, but it also offers lessons on how to breach these barriers. We conclude by discussing lessons for regulators, developers, and for Indigenous peoples striving to gain or maintain seats at the decision-making table.

First, for regulators, the ACP case study highlights the importance of early engagement together with accurate use of demographic data. Opposition by Tribes and Indigenous organizations grew slowly over time, but much of the momentum traces directly to FERC's decisions not to acknowledge racial disparities in pipeline routing and to deny formal consultation with affected Tribes. These kinds of decisions have major implications for environmental justice [76], and regulators can strengthen their implementation of environmental justice policies in the future by responding more thoughtfully and deliberately to requests and expectations of Indigenous peoples. By keeping Tribal nations at arm's length throughout the pre-filing, scoping, and review process, FERC not only missed valuable perspectives for decision-making, but the agency likely damaged relationships with Tribal governments and with Indigenous peoples in general. These relationships are important for environmental decision-making, because Indigenous peoples are best equipped to articulate their own perspectives. 
Piecemeal extraction and de-contextualization of Indigenous knowledges by developers and other intermediaries can miss nuances and introduce biases [198]. Repairing damaged relationships will be difficult, but a necessary first step is to acknowledge the importance of exceeding minimum legal standards for Tribal engagement when regulated activities have implications for Indigenous peoples.

Second, the case study highlights a unique relationship between FERC and pipeline developers that poses risks for Tribes but also presents an opportunity for amplifying Indigenous voices. Specifically, the agency's 2017 directive that pipeline developers communicate directly with Tribes fueled a common misperception that corporate engagement is synonymous with Tribal consultation. Developers may sometimes play a role in Tribal consultation, but consultation is ultimately an interaction between federal and Tribal governments meant to inform the environmental review process with Indigenous perspectives [147]. Corporate engagement, on the other hand, often focuses on recruiting support for a project or identifying compromises that may require minor modifications (e.g., fine-tuning a route based on landowner input). This type of engagement may help obtain a social license to operate e.g., [199], but it does not necessarily respond to concerns that Indigenous peoples have about their territories, which may include broad landscapes and the communities that rely directly on land and water for their livelihoods and cultural identities.

If developers truly want Indigenous perspectives on the impacts of pipelines and other infrastructure, then they should insist on meaningful government-to-government consultations with affected Tribes regardless of recognition status. In fact, developers hold unique power in this relationship: if regulators are unable to consult with Tribes due to ex parte rules or some other reason, developers are free to withdraw project applications from federal review until consultations are complete. This action would nullify ex parte concerns and help break down a major barrier for Native Nations, who frequently hold the least power in this situation. Withdrawing and resubmitting applications may create delays for developers, but developers also risk delays later on if they fail to consider Indigenous perspectives at the outset [35]. The most recent ruling in the DAPL case, which orders operators to shut down the pipeline until an adequate environmental review takes place, confirms this risk [77]. Regardless of the risks to developers, preemptively withdrawing permit applications could be an antidote to the mutually reinforcing entanglements that can otherwise limit Indigenous participation in environmental decision-making. Such advocacy by developers supports the beginning of Tribal sovereignty and represents a radical departure from engagement that simply seeks endorsement from people who happen to be Indigenous.

Third, we look to state governments, which have major opportunities to amplify the voices of Tribes in both state and federal decision-making. In the case of the ACP, North Carolina was responsible for authorizing stream and wetland crossings by the pipeline under Section 401 of the Clean Water Act, yet the state government-despite declaring formal political relationships with Tribes through state recognition-has no formal policy on consulting with Native nations. Tribal perspectives could have been particularly useful during the state's review of cumulative impacts to waterways, which involve the gradual degradation of environmental quality and human health as polluting infrastructure accumulates through time. Prospect and other Indigenous communities are well-equipped to comment on such long-term, accumulated impacts. Indeed, Indigenous knowledge systems often center the holistic perspective that regulators purportedly seek in their cumulative impact reviews [200]. Establishing formal consultation policies between state governments and state-recognized Tribal nations would be a commendable first step not only toward improved cumulative impact studies, but also toward the full and fair participation of Indigenous peoples in environmental decision-making and other areas of governance.

Presently, California's state government has the only Tribal consultation policy in the US that does not discriminate between federally recognized and non-recognized Native polities. The policy, codified by California lawmakers in 2014 [201], requires government decision-makers to consult with Tribes on topics beyond minor infrastructure route adjustments, including consultation on alternatives to projects. Although California's mandate has the same fundamental limitation as federal policy (i.e., 
consultation does not imply consent [202]), it could fill a major gap in cases where federal agencies insist on fulfilling only minimum legal consultation standards. Decision-makers in North Carolina and other states with large non-federally recognized Native populations have opportunities to build on California's example. Otherwise, state governments risk violating their duties to protect the beauty and integrity of the environment and to respect the rights of all peoples by failing to accord Native nations a place at the bargaining table.

We conclude with thoughts for Indigenous peoples. Tribal nations and individual Native people have been frustrated by the planning and permitting processes for the ACP and other fossil fuel projects. Although these frustrations are experienced across the range of recognition statuses by colonial governments, state-recognized Tribes experience additional barriers that promote invisibility in official proceedings and renew long entrenched "second class Indian" sentiments [33,34]. Nevertheless, Tribes and Native individuals may find encouragement and lessons in the case study. Resistance by Lumbee, Haliwa-Saponi, and other Indigenous peoples to the ACP has raised awareness about Native nations in North Carolina and elsewhere. Within Native communities, individuals have become more aware of public policies aimed at lowering barriers to participation in environmental decision-making (e.g., those pertaining to environmental justice and tribal consultation). As these barriers fall, however, Tribal governments and their citizens must be prepared to take on responsibilities for shared governance with colonial entities. Some of the responsibilities include heightened responsiveness to state and federal notices of environmental permitting, refusal to conflate corporate engagement with government-to-government consultation and detailed, proactive research on links between our own cultures and environments. Much of this work could be accomplished by establishing Tribal Historic Preservation Offices, although this is no small task for Tribes that are already under-resourced.

The case study shows that minimalist interpretations of Tribal consultation, environmental justice, and other policies reinforce the status quo, which is often to ignore the cultural and moral accountability of certain Native peoples toward their land and water because of their recognition status. More inclusive policies, however, when combined with well-resourced and responsive Tribal entities, have the potential to serve as powerful antidotes to structural barriers faced by Indigenous peoples, especially state-recognized or other non-federally recognized Tribes. The combination of inclusive policies and responsiveness by Native nations has the potential to cut deep into systems of decision-making in ways that amplify Indigenous voices, allowing the knowledge, perspectives, concerns, and values of Native peoples into decision-making spaces and lowering the barriers that often minimize Native peoples' participation in environmental governance.

Author Contributions: R.E.E. researched and outlined the study, R.E.E. and D.E.W. wrote the paper. All authors have read and agreed to the published version of the manuscript.

Funding: This work was funded partly by the University Faculty Scholars program at NC State. We received support for publication and open access from National Science Foundation Award Number HRD 1461441, administered through Northwest Indian College.

Acknowledgments: We are grateful to elected officials and others from the Haliwa-Saponi and Lumbee Tribes who contributed input and perspectives and pointed us toward source documents. We especially thank Jeff Anstead, Harvey Godwin, Jr., Freda Porter, and Danielle McLean for providing documents and helpful discussions. We thank Greg Jacobs and Philip Bell from the Coharie Tribe and Patrick Suarez from the Meherrin Tribe for beneficial conversations. We are grateful for historical perspectives from Louise Maynor and Malinda M. Lowery. Shelly Wilkins and two anonymous reviewers provided helpful feedback on the manuscript. This work was funded partly by the University Faculty Scholars program at NC State.

Conflicts of Interest: The authors declare no conflict of interest.

\section{References}

1. Bark, R.H.; Garrick, D.E.; Robinson, C.J.; Jackson, S. Adaptive basin governance and the prospects for meeting Indigenous water claims. Environ. Sci. Policy 2012, 19, 169-177. [CrossRef]

2. Chaffin, B.; Garmestani, A.S.; Gosnell, H.; Craig, R.K. Institutional networks and adaptive water governance in the Klamath River Basin, USA. Environ. Sci. Policy 2016, 57, 112-121. [CrossRef] 
3. Cosens, B.A.; Williams, M.K. Resilience and water governance: Adaptive governance in the Columbia River Basin. Ecol. Soc. 2012, 17. [CrossRef]

4. Umoff, A.A. Analysis of the 1944 U.S.-Mexico Water Treaty: Its past, present, and future. Env. Envtl. L. Pol'y J. 2008, 32, 69 .

5. Milman, A.; Scott, C.A. Beneath the surface: Intranational institutions and management of the United States-Mexico transboundary Santa Cruz aquifer. Environ. Plan. C Politics Space 2010, 28, 528-551. [CrossRef]

6. Flaherty, B.; Pacheco-Vega, R.; Isaac-Renton, J. Moving forward in Canada-United States transboundary water management: An analysis of historical and emerging concerns. Water Int. 2011, 36, 924-936. [CrossRef]

7. Bell, D.A. Columbia River Treaty Renewal and Sovereign Tribal Authority under the Stevens Treaty Right-to-Fish Clause. Public Land Resour. Law Rev. 2015, 36, 269.

8. Norman, E.S.; Bakker, K. Transgressing scales: Water governance across the Canada-US borderland. Ann. Assoc. Am. Geogr. 2009, 99, 99-117. [CrossRef]

9. von der Porten, S.; de Loë, R. Water governance and Indigenous governance: Towards a synthesis. Indig. Policy J. 2013, 23, 1-12.

10. United Nations United Nations Declaration on the Rights of Indigenous Peoples; United Nations: New York, NY, USA, 2007.

11. Curran, D. Indigenous processes of consent: Repoliticizing water governance through legal pluralism. Water 2019, 11, 571. [CrossRef]

12. Marshall, V. Overturning aqua nullius: Pathways to national law reform. In New Directions for Law in Australia: Essays in Contemporary Law Reform; Levy, R., O’Brien, M., Rice, S., Ridge, P., Thornton, M., Eds.; Australian National University Press: Acton, Middlesex, MA, USA, 2017; p. 221.

13. Norman, E.S. Standing up for inherent rights: The role of indigenous-led activism in protecting sacred waters and ways of life. Soc. Nat. Resour. 2017, 30, 537-553. [CrossRef]

14. O'Faircheallaigh, C.; Corbett, T. Indigenous participation in environmental management of mining projects: The role of negotiated agreements. Environ. Politics 2005, 14, 629-647. [CrossRef]

15. Norman, E.S. Finding common ground: Negotiating downstream rights to harvest with upstream responsibilities to protect-Dairies, berries, and shellfish in the Salish Sea. Glob. Environ. Politics 2019, 19, 77-97. [CrossRef]

16. Whyte, K. The Dakota access pipeline, environmental injustice, and US colonialism. Red Ink Int. J. Indig. Lit. Arts Humanit. 2017, 19, 1.

17. Blumm, M.C. Indian treaty fishing rights and the environment: Affirming the right to habitat protection and restoration. Wash. Law Rev. 2017, 92, 1. [CrossRef]

18. Brown, J.J. Treaty rights: Twenty years after the boldt decision. Wicazo Sa Rev. 1994, 10, 1-16. [CrossRef]

19. Salmond, A.; Brierley, G.; Hikuroa, D. Let the rivers speak. Policy Q. 2019, 15. [CrossRef]

20. Smith, A.V. The Klamath River now has the legal rights of a person. High Country News, 24 September 2019.

21. Rivers Are Relatives. Native America Calling, 11 October 2019.

22. Charpleix, L. The Whanganui River as Te Awa Tupua: Place-Based law in a legally pluralistic society. Geogr. J. 2018, 19-30. [CrossRef]

23. Chief, K.; Emanuel, R.; Conroy-Ben, O. Indigenous symposium on water research, education, and engagement. Eos 2019, 100. [CrossRef]

24. Hopi Water Declaration. Available online: https://www.crossingworlds.org/hopi-water-declaration/ (accessed on 1 May 2020).

25. Lumbee Tribe Reclamation of the Lumbee River's Ancestral Name 2009. Available online: https://www. lumbeetribe.com/tribal-ordinances (accessed on 1 May 2020).

26. National Environmental Justice Advisory Council. Guide on Consultation and Collaboration with Indian Tribal Governments and the Public Participation of Indigenous Groups and Tribal Members in Environmental Decision Making; Environmental Protection Agency: Washington, DC, USA, 2000.

27. Sweeney, R. Federal acknowledgement of Indian Tribes: Current bia interpretations of the federal criteria for acknowledgment with respect to several northwest tribes. Am. Indian Law Rev. 2001, 26, 203-231. [CrossRef]

28. U.S. Advisory Council on Historic Preservation. Guide to Working with Non-Federally Recognized Tribes in the Section 106 Process; Advisory Council on Historic Preservation: Washington, DC, USA, 2017. 
29. McCulloch, A.M.; Wilkins, D.E. "Constructing" nations within states: The quest for federal recognition by the catawba and lumbee tribes. Am. Indian Q. 1995, 19, 361-388. [CrossRef]

30. Wilson, N.J.; Inkster, J. Respecting water: Indigenous water governance, ontologies, and the politics of kinship on the ground. Environ. Plan. E Nat. Space 2018, 1, 516-538. [CrossRef]

31. Wilson, N.J.; Harris, L.M.; Joseph-Rear, A.; Beaumont, J.; Satterfield, T. Water is medicine: Reimagining water security through Tr'ondëk Hwëch'in relationships to treated and traditional water sources in Yukon, Canada. Water 2019, 11, 624. [CrossRef]

32. Sanchez, J.C.; Roberts, J. Transboundary Water Governance: Adaptation to Climate Change; IUCN Environmental Law Centre (ELC): Bonn, Germany, 2014.

33. Padget, C.D. The lost Indians of the lost colony: A critical legal study of the Lumbee Indians of North Carolina. Am. Indian Law Rev. 1997, 21, 391-424. [CrossRef]

34. Legislative Hearing before the Subcommittee on Indian and Alaska Native Affairs of the Committee on Natural Resources; U.S. House of Representatives: Washington, DC, USA, 2011.

35. Emanuel, R.E. Flawed environmental justice analyses. Science 2017, 357, 260. [CrossRef] [PubMed]

36. Federal Energy Regulatory Commission. Section 2.3.3.1: Water body crossings. In Atlantic Coast Pipeline and Supply Header Project Final Environmental Impact Statement; Docket CP15-554-000 et al.; Federal Energy Regulatory Commission: Washington, DC, USA, 2017.

37. Spokesman Says Pipeline will Have Long-Term Benefits. The Record Delta, 19 September 2018.

38. Alvarez, R.A.; Zavala-Araiza, D.; Lyon, D.R.; Allen, D.T.; Barkley, Z.R.; Brandt, A.R.; Davis, K.J.; Herndon, S.C.; Jacob, D.J.; Karion, A. Assessment of methane emissions from the US oil and gas supply chain. Science 2018, 361, 186-188.

39. IPCC. Global Warming of $1.5{ }^{\circ} \mathrm{C}$. In An IPCC Special Report on the Impacts of Global Warming of 1.5 ${ }^{\circ} \mathrm{C}$ above Pre-Industrial Levels and Related Global Greenhouse Gas Emission Pathways, in the Context of Strengthening the Global Response to the Threat of Climate Change, Sustainable Development, and Efforts to Eradicate Poverty; Masson-Delmotte, V.P., Zhai, H.-O., Pörtner, D., Roberts, J., Skea, P.R., Shukla, A., Pirani, W., Moufouma-Okia, C., Péan, R., Pidcock, S., et al., Eds.; Intergovernmental Panel on Climate Change: Geneva, Switzerland, 2018.

40. Emanuel, R.E. Climate change in the Lumbee River watershed and potential impacts on the Lumbee Tribe of North Carolina. J. Contemp. Water Res. Educ. 2018, 163, 79-93. [CrossRef]

41. Lowery, M.M. The Lumbee Indians: An American Struggle; UNC Press Books: Chapel Hill, NC, USA, 2018; ISBN 978-1-4696-4638-1.

42. Emanuel, R.E. Water in the Lumbee world: A river and its people in a time of change. Environ. Hist. 2019, 24, 25-51. [CrossRef]

43. Dial, A.L.; Eliades, D.K. The Only Land I Know: A History of the Lumbee Indians; Syracuse University Press: Onondaga, NY, USA, 1975; ISBN 0-8156-0360-6.

44. Winters v United States (207 U.S. 564). 1908.

45. Shurts, J. Indian Reserved Water Rights: The Winters Doctrine in its Social and Legal Context, 1880s-1930s; University of Oklahoma Press: Norman, OK, USA, 2000; Volume 8.

46. Koenig, K.A.; Stein, J. State recognition of American Indian Tribes: A survey of state-recognized tribes and state recognition processes. In Recognition, Sovereignty Struggles, and Indigenous Rights in the United States; UNC Press Books: Chapel Hill, NC, USA, 2013; ISBN 9781469608099.

47. Cohen's Handbook of Federal Indian Law; LexisNexis: New York, NY, USA, 2019; ISBN 978-0-327-17152-2.

48. Federal Water Pollution Control Act (AKA the "Clean Water Act"). Volume 33 U.S.C. Chapter 26, Sections 1251-1387.

49. Getches, D.H. Water Law in a Nutshell; Thomson West: Eagan, MN, USA, 2009.

50. Pevar, S.L. The Rights of Indians and Tribes; Oxford University Press: New York, NY, USA, 2012; ISBN 978-0-19-991343-5.

51. Wilkins, D.E.; Lomawaima, K.T. Uneven Ground: American Indian Sovereignty and Federal Law; University of Oklahoma Press: Norman, OK, USA, 2001; ISBN 978-0-8061-3395-9.

52. Cherokee Preservation Foundation Environmental Preservation Enhances Cherokee's Sense of Place. Available online: http://cherokeepreservation.org/wp-content/uploads/2014/03/2017-Ga-du-gi.pdf (accessed on 20 May 2020). 
53. U.S. Environmental Protection Agency Tribal Nonpoint Source Programs: Working to Solve Water Quality Problems 2019. Available online: https://www.epa.gov/sites/production/files/2015-09/documents/2010_02_ 19_nps_tribal_pdf_tribal_handbook2010.pdf (accessed on 1 May 2020).

54. Van Dam, C. Indigenous territories and REDD in Latin America: Opportunity or threat? Forests 2011, 2, 394-414. [CrossRef]

55. Jodoin, S. Transnational legal process and discourse in environmental governance: The case of REDD+ in Tanzania. Law Soc. Inq. 2019, 44, 1019-1050. [CrossRef]

56. Whyte, K. Too late for indigenous climate justice: Ecological and relational tipping points. WIREs Clim. Chang. 2020, 11, e603. [CrossRef]

57. Nursey-Bray, M.; Palmer, R.; Smith, T.F.; Rist, P. Old ways for new days: Australian Indigenous peoples and climate change. Local Environ. 2019, 24, 473-486. [CrossRef]

58. Estes, N.; Dhillon, J. (Eds.) Standing with Standing Rock; University of Minnesota Press: Minneapolis, MN, USA, 2019; ISBN 978-1-5179-0536-1.

59. Schapper, A.; Urban, F. Large dams, norms and Indigenous Peoples. Dev. Policy Rev. 2019, 00, 1-12. [CrossRef]

60. Diver, S. Native water protection flows through self-determination: Understanding tribal water quality standards and "treatment as a state.". J. Contemp. Water Res. Educ. 2018, 163, 6-30. [CrossRef]

61. Chief, K. Emerging voices of tribal perspectives in water resources. J. Contemp. Water Res. Educ. 2018, 163, 1-5. [CrossRef]

62. Jacob, C.; McDaniels, T.; Hinch, S. Indigenous culture and adaptation to climate change: Sockeye salmon and the St'át'imc people. Mitig. Adapt. Strateg. Glob. Chang. 2010, 15, 859-876. [CrossRef]

63. Hunter, R.; Silliman, S.W.; Landon, D.B. Shellfish collection and community connections in Eighteenth-Century Native New England. Am. Antiq. 2014, 79, 712-729. [CrossRef]

64. Nelson, M.K. Protecting the sanctity of native foods. In State of the World 2013: Is Sustainability Still Possible? Island Press/Center for Resource Economics: Washington, DC, USA, 2013; pp. 201-209. ISBN 978-1-61091-458-1.

65. Lowery, M.M. Lumbee Indians in the Jim Crow South: Race, Identity, and the Making of a Nation; Univ of North Carolina Press: Chapel Hill, NC, USA, 2010; ISBN 0-8078-3368-1.

66. Mitchell, T.A.; Casper, N.J.; Logan, L.T.; Colclazier, E.; Mitchell, K.J.R. Using Traditional Ecological Knowledge to Protect Wetlands: The Swinomish Tribe's Wetlands Cultural Assessment Project. Unpublished Manuscript. 2020.

67. Wilkins, D.E. Documents of Native American Political Development: 1933 to Present; Oxford University Press: Oxford, UK, 2019; ISBN 978-0-19-021207-0.

68. Privott, M. An ethos of responsibility and indigenous women water protectors in the \#NoDAPL movement. Am. Indian Q. 2019, 43, 74-100.

69. Treuer, D. An Indian Protest for Everyone (Opinion). The New York Times, 26 November 2016.

70. Petersen-Perlman, J.D.; Fischhendler, I. The weakness of the strong: Re-Examining power in transboundary water dynamics. Int. Environ. Agreem. 2018, 18, 275-294. [CrossRef]

71. Tyler, N.; Tyler, I.R.; Ligibel, T.J. Historic Preservation, Third Edition: An Introduction to Its History, Principles, and Practice, 3rd ed.; W. W. Norton \& Company: New York, NY, USA, 2018; ISBN 978-0-393-71298-8.

72. Marincic, A.M. The national historic preservation act: An inadequate attempt to protect the cultural and religious sites of native nations. Iowa Law Rev. 2017, 103, 1777.

73. Ball, D.; Clayburn, R.; Cordero, R.; Edwards, B.; Grussing, V.; Ledford, J.; McConnell, R.; Monette, R.; Steelquist, R.; Thorsgard, E.; et al. Characterizing Tribal Cultural Landscapes; US Bureau of Ocean Energy Management: Washington, DC, USA, 2017; p. 66.

74. Executive Order Number 12898: Federal Actions to Address Environmental Justice in Minority Populations and Low-Income Populations 1994. Available online: https://www.archives.gov/federal-register/executiveorders/1994.html\#12898 (accessed on 1 May 2020).

75. Johnson, T.N. The dakota access pipeline and the breakdown of participatory processes in environmental decision-making. Environ. Commun. 2019, 13, 335-352. [CrossRef]

76. Whyte, K.P. The recognition dimensions of environmental justice in Indian Country. Environ. Justice 2011, 4, 199-205. [CrossRef]

77. Standing Rock Sioux Tribe v US Army Corps of Engineers (16-1534 DC Cir.). 2020. 
78. U.S. Department of Interior; U.S. Department of the Army; U.S. Department of Justice. Improving Tribal Consultation and Preparing for the Future of Tribal Involvement in Federal Infrastructure Decisions; U.S. Department of Interior; U.S. Department of the Army; U.S. Department of Justice: Washington, DC, USA, 2017.

79. Harrison, J.L. From the Inside Out: The Fight for Environmental Justice within Government Agencies; MIT Press: Cambridge, MA, USA, 2019; ISBN 978-0-262-35542-1.

80. End of Mission Statement by the United Nations Special Rapporteur on the Rights of Indigenous Peoples, Victoria Tauli-Corpuz of her Visit to the United States of America. 2017. Available online: http://www.ohchr. org/EN/NewsEvents/Pages/DisplayNews.aspx?NewsID=21274 (accessed on 1 May 2020).

81. United South and Eastern Tribes Comment of United South and Eastern Tribes Sovereignty Protection Fund under PL18-1 (Federal Energy Regulatory Commission). 2018.

82. Evans, L.E. Power from Powerlessness: Tribal Governments, Institutional Niches, and American Federalism; Oxford University Press: Oxford, UK, 2011; ISBN 978-0-19-045390-9.

83. Reo, N.J.; Whyte, K.P.; McGregor, D.; Smith, M.; Jenkins, J.F. Factors that support Indigenous involvement in multi-actor environmental stewardship. Altern. Int. J. Indig. Peoples 2017, 13, 58-68. [CrossRef]

84. U.S. Geological Survey. The USGS at Embudo, New Mexico: 125 Years of Systematic Stream gaging in the United States (Fact Sheet 2014-3034); U.S. Geological Survey: Reston, VA, USA, 2014.

85. Wyllie de Echeverria, V.R.; Thornton, T.F. Using traditional ecological knowledge to understand and adapt to climate and biodiversity change on the Pacific coast of North America. Ambio 2019, 48, 1447-1469. [CrossRef] [PubMed]

86. Doyle, J.T.; Redsteer, M.H.; Eggers, M.J. Exploring effects of climate change on Northern Plains American Indian health. In Climate Change and Indigenous Peoples in the United States: Impacts, Experiences and Actions; Maldonado, J.K., Colombi, B., Pandya, R., Eds.; Springer International Publishing: Cham, Switzerland, 2014; pp. 135-147. ISBN 978-3-319-05266-3.

87. Whyte, K. Settler colonialism, ecology, and environmental injustice. Environ. Soc. 2018, 9. [CrossRef]

88. North Carolina Commission of Indian Affairs Map of NC Tribal Communities. Available online: https: //ncadmin.nc.gov/public/american-indians/map-nc-tribal-communities (accessed on 3 July 2020).

89. What Definitions Clarify the Meaning of the Provisions of This Part? (25 CFR § 20.100). 2001; p. 66 FR.

90. Moten, D.E. Racial integrity or 'Race Suicide': Virginia's eugenic movement, W. E. B. Du Bois, and the work of Walter A. Plecker. Negro Hist. Bull. 1999, 62, 6.

91. Bryant, J. State secret: North Carolina and the cherokee trail of tears. J. Am. Indian Educ. 2008, 47, 3-21.

92. Warner, C.K. A study of state social studies standards for American Indian Education. Multicult. Perspect. 2015, 17, 125-132. [CrossRef]

93. Hunt, B.D.; Locklear, L.; Bullard, C.; Pacheco, C. "Do you live in a teepee? Do you have running water?" The harrowing experiences of American Indians in North Carolina's Urban K-12 Schools. Urban Rev. 2020, 1-19. [CrossRef]

94. Dunbar-Ortiz, R. An Indigenous Peoples' History of the United States; Beacon Press: Boston, MA, USA, 2014; ISBN 978-0-8070-0041-0.

95. Sun, G. Impacts of climate change and variability on water resources in the Southeast USA. In Climate of the Southeast United States: Variability, Change, Impacts, and Vulnerability; Ingram, K.T., Dow, K., Carter, L., Anderson, J., Eds.; NCA Regional Input Reports; Island Press/Center for Resource Economics: Washington, DC, USA, 2013; pp. 210-236. ISBN 978-1-61091-509-0.

96. Anderson, W.P.; Emanuel, R.E. Effect of interannual and interdecadal climate oscillations on groundwater in North Carolina. Geophys. Res. Lett. 2008, 35, L23402. [CrossRef]

97. Nippgen, F.; McGlynn, B.L.; Emanuel, R.E.; Vose, J.M. Watershed memory at the Coweeta Hydrologic Laboratory: The effect of past precipitation and storage on hydrologic response. Water Resour. Res. 2016. [CrossRef]

98. Pratt, J.H. Drainage of North Carolina swamp lands. J. Elisha Mitchell Sci. Soc. 1909, 25, 158-163.

99. Maxwell, W. The Back Swamp drainage project, Robeson County, North Carolina: Biopolitical intervention in the lives of Indian farmers. Water Hist. 2017, 9, 9-28. [CrossRef]

100. McMullan, P.S. North Carolina's Blacklands Treasure; Pamlico \& Albemarle Publishing: Nags Head, NC, USA, 2016.

101. Doyle, M. The Source: How Rivers Made America and America Remade Its Rivers; W. W. Norton \& Company: New York, NY, USA, 2018; ISBN 978-0-393-24236-2. 
102. Cushman, R.M. Review of ecological effects of rapidly varying flows downstream from hydroelectric facilities. N. Am. J. Fish. Manag. 1985, 5, 330-339. [CrossRef]

103. Bendor, T. A dynamic analysis of the wetland mitigation process and its effects on no net loss policy. Landsc. Urban Plan. 2009, 89, 17-27. [CrossRef]

104. Ruhl, J.B. Water wars, eastern style: Divvying up the apalachicola-chattahoochee-flint river basin. J. Contemp. Water Res. Educ. 2005, 131, 47-54. [CrossRef]

105. Tribe, W.S. Waccamaw Siouan Indians. Available online: https://waccamaw-siouan.org/history (accessed on 1 July 2020).

106. Great Coharie River Initiative. Available online: https://coharietribe.org/programs/great-coharie-riverinitiative/ (accessed on 1 July 2020).

107. Executive Order Number 80: North Carolina's Commitment to Address Climate Change and Transition to a Clean Energy Economy. 2018. Available online: https://files.nc.gov/governor/documents/files/EO80$\% 20$ NC $\% 27$ s $\% 20$ Commitment $\% 20$ to $\% 20$ Address $\% 20$ Climate $\% 20$ Change $\% 20 \% 26 \% 20$ Transition $\% 20$ to $\%$ 20a\%20Clean\%20Energy\%20Economy.pdf (accessed on 20 May 2020).

108. Boughman, A.L.; Oxendine, L.O. Herbal Remedies of the Lumbee Indians; McFarland: Jefferson, NC, USA, 2003; ISBN 978-0-7864-2684-3.

109. State of North Carolina. North Carolina Climate Risk Assessment and Resilience Plan. 2020. Available online: https:/deq.nc.gov/energy-climate/climate-change/nc-climate-change-interagency-council/climatechange-clean-energy-17 (accessed on 20 May 2020).

110. Martin, K.L.; Emanuel, R.E.; Vose, J.M. Terra incognita: The unknown risks to environmental quality posed by the spatial distribution and abundance of concentrated animal feeding operations. Sci. Total Environ. 2018, 642, 887-893. [CrossRef]

111. Stith, P.; Warrick, J.; Sill, M. Boss Hog: The power of pork, North Carolina's pork revolution. Raleigh News $\mathcal{E}$ Observer, 19 February 1995.

112. Heaney, C.D.; Myers, K.; Wing, S.; Hall, D.; Baron, D.; Stewart, J.R. Source tracking swine fecal waste in surface water proximal to swine concentrated animal feeding operations. Sci. Total Environ. 2015, 511, 676-683. [CrossRef]

113. JoAnn, B.; Bob, L.; Peter, W.; Susan, H.; Dana, K.; Thorne, P.S.; Michael, W. Impacts of waste from concentrated animal feeding operations on water quality. Environ. Health Perspect. 2007, 115, 308-312. [CrossRef]

114. Mallin, M.A.; McIver, M.R.; Robuck, A.R.; Dickens, A.K. Industrial swine and poultry production causes chronic nutrient and fecal microbial stream pollution. Water Air Soil Pollut. 2015, 226, 407. [CrossRef]

115. Edwards, B.; Ladd, A.E. Environmental justice, swine production and farm loss in North Carolina. Sociol. Spectr. 2000, 20, 263-290. [CrossRef]

116. Burmeister, L. Lagoons, litter and the law: CAFO regulation as social risk politics. South. Rural Sociol. 2002, 18, 56-87.

117. Newcombe, C.P.; Jensen, J.O.T. Channel suspended sediment and fisheries: A synthesis for quantitative assessment of risk and impact. N. Am. J. Fish. Manag. 1996, 16, 693-727. [CrossRef]

118. U.S. Army Corps of Engineers-Omaha District Fact Sheet: Nationwide Permit Reissuance 2017. Available online: https://www.usace.army.mil/Media/Fact-Sheets/Fact-Sheet-Article-View/Article/1043655/nationwidepermit-reissuance/ (accessed on 1 May 2020).

119. Arkfeld, A. Nationwide permit 12 and domestic oil pipelines: An incompatible relationship? Wash. Law Rev. 2017, 92, 1991.

120. Hinds, B. Twenty-Five Years later: The amendments to the national historic preservation act and tribal consultation. Am. Indian Law Rev. 2017, 42, 141-171.

121. Wolfley, J. Mni Wiconi, tribal sovereignty, and treaty rights: Lessons from the Dakota Access Pipeline. Energy Justice 2018, 141-165. [CrossRef]

122. State of North Carolina Water Quality General Certification No. 4133: General Certification for Projects Eligible for US Army Corps of Engineers Nationwide Permit 12 2017. Available online: https:/deq.nc.gov/ about/divisions/water-resources/water-quality-permitting/401-buffer-permitting-branch/general (accessed on 1 May 2020).

123. U.S. Army Corps of Engineers-Wilmington District 2017 Nationwide Permits: Pre-construction Notification. Available online: https:/www.saw.usace.army.mil/Missions/Regulatory-Permit-Program/Permits/2017Nationwide-Permits/Pre-construction-Notification/ (accessed on 4 July 2020). 
124. Freda, P.; Administrator, Lumbee Tribe, Pembroke, North Carolina. Personal Communication, 2020.

125. Hunter, T.C. Mitigation Work Plods Slowly Along. The Robesonian, 7 June 2019.

126. DeVane, S. FEMA to pay $\$ 11$ million for Robeson County homes. Fayetteville Observer, 22 June 2018.

127. Duke Energy Duke Energy, Piedmont Natural Gas Select Dominion to Build 550-mile "Atlantic Coast Pipeline" to Transport Natural Gas from West Virginia to eastern North Carolina. (Press Release). 2014. Available online: https://news.duke-energy.com/releases/duke-energy-piedmont-natural-gas-select-dominion-to-build550-mile-atlantic-coast-pipeline-to-transport-natural-gas-from-west-virginia-to-eastern-north-carolina (accessed on 1 May 2020).

128. Dominion seeks more time to complete U.S. Atlantic Coast natgas pipe. Reuters, 17 June 2020.

129. Duke Energy. Connected-2014 Sustainability Report; Duke Energy: Charlotte, NC, USA, 2015.

130. Dominion Energy. 2018 Sustainability \& Corporate Responsibility Report; Dominion Energy: Richmond, VA, USA, 2018.

131. Yafei, J.; Mustafa, A.; Xiaobo, C.; Zhang, Y. Numerical simulations of spilled coal ash in the dan river and the environmental impact of the incident. World Environ. Water Resour. Congr. 2016, 114-125. [CrossRef]

132. Lemly, A.D. An urgent need for an EPA standard for disposal of coal ash. Environ. Pollut. 2014, 191, $253-255$. [CrossRef] [PubMed]

133. Yates, L. Letters to the editor: "sparks fly over coal-ash cleanup-duke energy's response.". Raleigh News Observer, 3 December 2017.

134. Sweet, C. C-Suite strategies (A special report)-Power's past and future: Duke Energy's CEO Lynn Good on how a coal-heavy utility is coping in a rapidly changing energy world. Wall Street Journal, 2 October 2016.

135. Brown, E. Pipeline architects with project since inception work through obstacles, criticism. Nelson County Times, 27 December 2017.

136. Schilling-Estes, N. Investigating intra-ethnic differentiation: /ay/ in Lumbee Native American English. Lang. Var. Chang. 2000, 12, 141-174. [CrossRef]

137. Smith, J.M.; Smith, L.J. The Lumbee Methodists: Getting to Know Them, a Folk History; Commission of Archives and History, North Carolina Methodist Conference: Raleigh, NC, USA, 1990.

138. Anderson, R.K. Lumbee kinship, community, and the success of the red banks mutual association. Am. Indian Q. 1999, 23, 39-58. [CrossRef]

139. Scheirbeck, H.M. Questions and answers about the NC Indian cultural center. Carol. Indian Voice, 13 May 1990.

140. 140. Pipeline Construction Now Started; Route is Mapped. Rocky Mount Telegram, 6 August 1959.

141. Dominion Energy Atlantic Coast Pipeline: FERC Pre-Filing Process. 2014. Available online: https: //atlanticcoastpipeline.com/resources/docs/resources/acp-pf8-ferc-process.pdf (accessed on 1 May 2020).

142. Dominion Energy Atlantic Coast Pipeline Fact Sheet 2014. (On file with author).

143. Atlantic Coast Pipeline. Resource Report 5-Socioeconomics (Draft) Prepared by Natural Resource Group, an ERM Group Company; ERM: Richmond, VA, USA, 2015.

144. Atlantic Coast Pipeline. Resource Report 5-Socioeconomics (Final) Prepared by Natural Resource Group, an ERM Group Company; ERM: Richmond, VA, USA, 2015.

145. Consultation with Indian Tribes in the Section 106 Review Process: A Handbook; Advisory Council on Historic Preservation: Washington, DC, USA, 2012.

146. Executive Order Number 13175: Consultation and Coordination with Indian Tribal Governments 2000. Available online: https://www.federalregister.gov/documents/2000/11/09/00-29003/consultation-andcoordination-with-indian-tribal-governments (accessed on 1 May 2020).

147. Routel, C.; Holth, J. Toward genuine tribal consultation in the 21st century. Univ. Mich. J. Law Reform 2013, $46,417-475$.

148. U.S. Government Accountability Office. Tribal Consultation: Additional Federal Actions Needed for Infrastructure Projects; US Government Accountability Office: Washington, DC, USA, 2019.

149. Coushatta Tribe of Louisiana Comment of Coushatta Tribe of Louisiana Tribal Historic Preservation Office under PL18-1 (Federal Energy Regulatory Commission). 2018.

150. Dominion Energy Atlantic Coast Pipeline: Project Overview. 2016. Available online: https:// atlanticcoastpipeline.com/resources/docs/resources/acp-pf1-project-overview.pdf (accessed on 1 May 2020). 
151. Chmura Economics \& Analytics. The Economic Impact of the Atlantic Coast Pipeline in West Virginia, Virginia, and North Carolina. 2014. Available online: https://www.coastalreview.org/wp-content/uploads/ 2017/03/acp-chmura-report-091014-1-1.pdf (accessed on 1 May 2020).

152. Dominion Energy Previously Unfiled Correspondence with State Recognized Indian Tribes in Correspondence to FERC Re: Docket Nos. CP15-554-000 et al. 2016.

153. Dominion Transmission, Inc. Response to 11/17/16 and 11/22/16 Data Requests of Atlantic Coast Pipeline, LLC, et. al. under CP15-554, et. al. 2016.

154. Overberg, V.B.; McWhirter, C.; Overberg, P. Hurricane Matthew Hits a North Carolina Tribe Particularly Hard. Wall Street Journal, 14 October 2016.

155. U.S. Federal Energy Regulatory Commission. Draft Environmental Impact Statement for the Atlantic Coast Pipeline; Federal Energy Regulatory Commission: Washington, DC, USA, 2016.

156. Skiba, R.J.; Michael, R.S.; Nardo, A.C.; Peterson, R.L. The color of discipline: Sources of racial and gender disproportionality in school punishment. Urban Rev. 2002, 34, 317-342. [CrossRef]

157. MacMillan, D.L.; Reschly, D.J. Overrepresentation of minority students: The case for greater specificity or reconsideration of the variables examined. J. Spec. Educ. 1998, 32, 15-24. [CrossRef]

158. Lumbee Tribe Comments of Lumbee Tribe of North Carolina to Federal Energy Regulatory Commission Re: Docket Numbers CP15-554-000 et al. 2017.

159. National Congress of American Indians Resolution \#MOH-17-054: Federal Energy Regulatory Commission to fulfill its obligations to Indian Tribes in Pipeline Permitting. 2017. Available online: https://files.nc.gov/ncdeq/Energy\%20Mineral\%20and\%20Land\%20Resources/DEMLR/Atlantic-CoastPipeline/National\%20Congress\%20of\%20American\%20Indians\%20-\%20Resolution\%20Against \%20ACP\% 20June\%2012\%202017.pdf (accessed on 1 May 2020).

160. Federal Energy Regulatory Commission. Atlantic Coast Pipeline and Supply Header Project Draft Environmental Impact Statement. Docket CP15-554-000 et al. 2016.

161. Federal Energy Regulatory Commission. Environmental Information Request for the Atlantic Coast Pipeline and Supply Header Project. Docket CP15-554-000 et al. 2017.

162. Federal Energy Regulatory Commission. Guidelines for Reporting on Cultural Resources Investigations for Natural Gas Projects; Federal Energy Regulatory Commission: Washington, DC, USA, 2017; p. 37.

163. Colwell, C. How the Archaeological Review behind the Dakota Access Pipeline went Wrong? Available online: http://theconversation.com/how-the-archaeological-review-behind-the-dakota-access-pipelinewent-wrong-67815 (accessed on 20 May 2020).

164. Lumbee Tribe Standing in Solidarity with Standing Rock, CLLR-2016-0906-01 2016. Available online: https://www.lumbeetribe.com/tribal-resolutions (accessed on 1 May 2020).

165. National Congress of American Indians. Infrastructure Projects Listening and Consultations Session Key Points; National Congress of American Indians: Phoenix, AZ, USA, 2016.

166. Coalition for American Heritage Comment of Coalition for American Heritage under PL18-1 (Federal Energy Regulatory Commission). 2018.

167. Haliwa Saponi Tribe Comments on Section 401 Certification Application for Construction of the Atlantic Coast Pipeline. 2017.

168. U.S. Federal Energy Regulatory Commission. Atlantic Coast Pipeline and Supply Header Project Final Environmental Impact Statement; Federal Energy Regulatory Commission: Washington, DC, USA, 2017.

169. U.S. Federal Energy Regulatory Commission. Order on Rehearing. Docket CP15-554-000 et al.; Federal Energy Regulatory Commission: Washington, DC, USA, 2018.

170. Dominion Energy APPENDIX A: Summary of Consultations with the Lumbee Indian Nation, Coharie Tribal Council, Haliwa-Saponi Tribe, and Meherrin Tribe. 2017.

171. Jeff, A.; Vice Chief, Haliwa-Saponi Tribe, Hollister, North Carolina. Personal Communication, 2018.

172. Brown, E. Atlantic Coast Pipeline receives key federal approvals. Lynchburg News and Advance, 14 February 2018.

173. Dominion Energy Phase I Historic Architectural Survey of the Atlantic Coast Pipeline: North Carolina Addendum 6 Report ER 14-1475 2018.

174. U.S. National Park Service National Register of Historic Places-Traditional Cultural Properties (TCPs) A Quick Guide for Preserving Native American Cultural Resources 2012. Available online: https:/www.nps. gov/history/tribes/documents/tcp.pdf (accessed on 1 May 2020). 
175. Panich, L.M.; Schneider, T.D. Categorical denial: Evaluating Post-1492 indigenous erasure in the paper trail of american archaeology. Am. Antiq. 2019, 84, 651-668. [CrossRef]

176. Lumbee Tribe Tribal Consultation and the Atlantic Coast Pipeline, CLLR-2018-0222-01. 2018. Available online: https://www.lumbeetribe.com/tribal-resolutions (accessed on 1 May 2020).

177. North Carolina Commission of Indian Affairs. Atlantic Coast Pipeline Resolution. No. 2018-001; 2018. Available online: https://files.nc.gov/ncdoa/Atlantic\%20Coast\%20Pipeline\%20-\%20Resolution\%23\%202018001.pdf (accessed on 1 May 2020).

178. Supplemental Environmental Impact Statements (23 C.F.R., Section 771.130).

179. Appalachian Voices v FERC (18-1114 4th Cir.). 2018.

180. DC Circuit Grills FERC on Use of Tolling Orders on Atlantic Sunrise Pipeline, Other Natural Gas Projects. Available online: https://www.utilitydive.com/news/dc-circuit-grills-ferc-on-use-of-tolling-orderson-atlantic-sunrise-pipelin/576882/ (accessed on 25 May 2020).

181. Grover, S. For whom the toll tolls. Natural Resources E Environment (American Bar Association). 2020, pp. 55-57. Available online: https://search.proquest.com/docview/2369315997 (accessed on 1 May 2020).

182. NC WARN; Clean Water for NC; Blue Ridge Environmental Defense League ("BREDL") and its chapters, Concerned Stewards of Halifax County, Nash Stop the Pipeline, Wilson County No Pipeline, No Pipeline Johnston County, Cumberland County Caring Voices; EcoRobeson; Concerned Citizens of Tillery; Concerned Citizens of Northampton County; Friends of the Earth; the NC Environmental Justice Network. Title VI Environmental Justice Complaint against NC Department of Environmental Quality; Filed with US Environmental Protection Agency: Washington, DC, USA, 2018. Available online: https://www.ncwarn.org/wp-content/ uploads/Title-VI-complaint-FINAL.pdf (accessed on 1 May 2020).

183. Sierra Club v US Department of Interior (18-1082 4th Cir. 2018).

184. Sorg, L. Document reveals effort to remove opposition of Native American tribes to the Atlantic Coast Pipeline. NC Policy Watch, 31 January 2019.

185. Lumbee Tribe Message from Chairman Harvey Godwin, Jr. Available online: https://www.facebook.com/ lumbeetribenc/posts/1594957897272539 (accessed on 1 May 2020).

186. Harvey, G., Jr.; Chairman, Lumbee Tribe, Pembroke, North Carolina. Personal Communication, 2020.

187. Duke Energy Dominion Energy and Duke Energy Cancel the Atlantic Coast Pipeline. Available online: https://news.duke-energy.com/releases/dominion-energy-and-duke-energy-cancel-the-atlanticcoast-pipeline (accessed on 15 July 2020).

188. Vogelsong, S. What sank the Atlantic Coast Pipeline? It wasn't just environmentalism. Virginia Mercury, 8 July 2020.

189. Norman, E. Cultural politics and transboundary resource governance in the Salish Sea. Water Altern. 2012, 5, 138.

190. Singh, G.G.; Lerner, J.; Mach, M.; Murray, C.C.; Ranieri, B.; St-Laurent, G.P.; Wong, J.; Guimaraes, A.; Yunda-Guarin, G.; Satterfield, T.; et al. Scientific shortcomings in environmental impact statements internationally. People Nat. 2020, 2, 369-379. [CrossRef]

191. Foth, M. Barriers to aboriginal participation in environmental assessment: A case study of the Wuskwatim generating station, Manitoba. Master's Thesis, University of Manitoba, Winnipeg, Manitoba, 2011.

192. Dalseg, S.K.; Kuokkanen, R.; Mills, S.; Simmons, D. Gendered environmental assessments in the canadian north: Marginalization of indigenous women and traditional economies. North. Rev. 2018, 135-166. [CrossRef]

193. Williams, A.; Emamdjomeh, A. America is More Diverse than Ever-But Still Segregated. Washington Post, 10 May 2018.

194. Wraight, S.; Hofmann, J.; Allpress, J.; Depro, B. Environmental Justice Concerns and the Proposed Atlantic Coast Pipeline Route in North Carolina; RTI Press: Research Triangle Park, NC, USA, 2018. [CrossRef]

195. Petersen, J. The Atlantic Coast Pipeline: Power, Environmental Justice, and Artful Resistance. Master's Thesis, Ohio University, Athens, OH, USA, 2020.

196. Federal Court Revokes Gas Project Permit in Win for Historic African American Community in Va. Available online: https://www.washingtonpost.com/local/virginia-politics/federal-court-revokes-gas-project-permitin-win-for-historic-african-american-community/2020/01/07/76bb3538-3170-11ea-a053-dc6d944ba776_ story.html (accessed on 4 July 2020). 
197. Bunyasi, T.L.; Smith, C.W. Stay Woke: A People's Guide to Making All Black Lives Matter; New York University Press: New York, NY, USA, 2019; ISBN 978-1-4798-3231-6.

198. Stevenson, M.G. Indigenous knowledge in environmental assessment. Arctic 1996, 49, 278-291. [CrossRef]

199. Boiral, O.; Heras-Saizarbitoria, I.; Brotherton, M.-C. Corporate sustainability and indigenous community engagement in the extractive industry. J. Clean. Produc. 2019, 235, 701-711. [CrossRef]

200. Moore, M.-L.; von der Porten, S.; Castleden, H. Consultation is not consent: Hydraulic fracturing and water governance on Indigenous lands in Canada. WIREs Water 2017, 4, e1180. [CrossRef]

201. Native Americans: California Environmental Quality Act. 2014. Available online: https://leginfo.legislature. ca.gov/faces/billNavClient.xhtml?bill_id=201320140AB52 (accessed on 1 May 2020).

202. Manning, B.R.M. Geographies of hope in cultural resources protection. Environ. Plan. E Nat. Space 2019. [CrossRef]

(C) 2020 by the authors. Licensee MDPI, Basel, Switzerland. This article is an open access article distributed under the terms and conditions of the Creative Commons Attribution (CC BY) license (http://creativecommons.org/licenses/by/4.0/). 